TITLE:

\title{
Novel catalytic behavior of Cu/Al2O3 catalyst against daily start-up and shut-down (DSS)-like operation in the water gas shift reaction
}

\section{$\operatorname{AUTHOR}(\mathrm{S})$ :}

Nishimura, Shun; Shishido, Tetsuya; Ebitani, Kohki; Teramura, Kentaro; Tanaka, Tsunehiro

\section{CITATION:}

Nishimura, Shun ... [et al]. Novel catalytic behavior of Cu/Al2O3 catalyst against daily startup and shut-down (DSS)-like operation in the water gas shift reaction. Applied Catalysis A: General 2010, 387(1-2): 185-194

\section{ISSUE DATE:}

2010-10-20

URL:

http://hdl.handle.net/2433/147184

\section{RIGHT:}

(c) 2010 Elsevier B.V.; この論文は出版社版でありません。引用の際には 出版社版をご確認ご利用ください。; This is not the published version. Please cite only the published version. 
Nishimura et al.

Novel catalytic behavior of $\mathrm{Cu} / \mathrm{Al}_{2} \mathrm{O}_{3}$ catalyst against daily start-up and shut-down (DSS)-like operation in the water gas shift reaction

\title{
Novel catalytic behavior of $\mathrm{Cu} / \mathrm{Al}_{2} \mathrm{O}_{3}$ catalyst against daily start-up and
}

\section{shut-down (DSS)-like operation in the water gas shift reaction}

\author{
Shun Nishimura, ${ }^{b}$ Tetsuya Shishido, ${ }^{* a}$ Kohki Ebitani, ${ }^{b}$ Kentaro Teramura ${ }^{c}$ \\ and Tsunehiro Tanaka ${ }^{a}$
}

\begin{abstract}
Affiliations
${ }^{a}$ Department of Molecular Engineering, Graduate School of Engineering, Kyoto University, Katsura, Kyoto 615-8510, Japan.

${ }^{b}$ School of Materials Science, Japan Advanced Institute of Science and Technology, Nomi, Ishikawa 923-1292, Japan.

${ }^{c}$ Kyoto University Pioneering Research Unit for Next Generation, Kyoto University, Katsura, Kyoto 615-8510, Japan.
\end{abstract}

\section{Corresponding author}

Dr. Tetsuya Shishido

Department of Molecular Engineering, Graduate School of Engineering, Kyoto University, Katsura, Kyoto 615-8510, Japan.

Tel: +81753832559

Fax: +81753832561

E-mail: shishido@moleng.kyoto-u.ac.jp 
Nishimura et al. Novel catalytic behavior of $\mathrm{Cu} / \mathrm{Al}_{2} \mathrm{O}_{3}$ catalyst against daily start-up and shut-down (DSS)-like operation in the water gas shift reaction

\section{Abstract}

$\mathrm{Cu} / \mathrm{Al}_{2} \mathrm{O}_{3}$ catalysts $(\mathrm{Cu} / \mathrm{Al}=1 / 2)$ have been prepared by co-precipitation $(\mathrm{CP}-)$, homogeneous precipitation (HP-), sol-gel (SG-), and impregnation (IMP-) methods. Prepared $\mathrm{Cu} / \mathrm{Al}_{2} \mathrm{O}_{3}$ catalysts were applied to the water gas shift (WGS) reaction. Effects of preparation method and calcination temperature on their activities for the WGS reaction and sustainability against the daily start-up and shut-down (DSS)-like operation between 323-473 K under steam treatment were investigated. CP-, HP-, and $\mathrm{SG}-\mathrm{Cu} / \mathrm{Al}_{2} \mathrm{O}_{3}$ catalysts showed a sustainable activity during DSS-like operation in the WGS reaction, whereas IMP-Cu/ $\mathrm{Al}_{2} \mathrm{O}_{3}$ showed a quite low sustainability. $\mathrm{CP}-\mathrm{Cu} / \mathrm{Al}_{2} \mathrm{O}_{3}$ catalyst calcined at $823 \mathrm{~K}(\mathrm{CP}-823)$ showed the highest activity and sustainability among the catalysts tested and almost similar to a commercial $\mathrm{Cu} / \mathrm{ZnO} / \mathrm{Al}_{2} \mathrm{O}_{3}$ catalyst (MDC-7) even after 50 cycles of the DSS-like operation in the WGS reaction. In contrast, $\mathrm{CP}-\mathrm{Cu} / \mathrm{Al}_{2} \mathrm{O}_{3}$ catalyst calcined at $1073 \mathrm{~K}(\mathrm{CP}-1073)$ showed a low sustainability, although the initial activity was higher than that of CP-823. It was concluded that such prominent performances of the CP-823 catalyst is caused by 1) the formation of highly dispersed and stable $\mathrm{Cu}$ metal and 2) an important role of boehmite $(\mathrm{AlO}(\mathrm{OH}))$ phase formed during the DSS operation in inhibition of aggregation of $\mathrm{Cu}$ metal particles. For CP-1073 K, "in-situ” formation of boehmite phase did not proceed due to the formation of stable $\mathrm{CuAl}_{2} \mathrm{O}_{4}$ phase by calcination at high temperature. Therefore, the activity of CP-1073 remarkably decreased as a result of aggregation of $\mathrm{Cu}$ metal particles during the DSS-like operation. 
Nishimura et al.

Novel catalytic behavior of $\mathrm{Cu} / \mathrm{Al}_{2} \mathrm{O}_{3}$ catalyst against daily start-up and shut-down (DSS)-like operation in the water gas shift reaction $3 / 46$

Key Words: Water gas shift reaction, DSS operation, $\mathrm{Cu} / \mathrm{Al}_{2} \mathrm{O}_{3}$ catalyst, High sustainability, Boehmite.

\section{Introduction}

The cogeneration system with the polymer electrolyte membrane fuel cells (PEMFCs) using $\mathrm{H}_{2}$ fuel is attractive as a new energy system because of their high power density, low temperature operation, low emissions of NOx, greenhouse gas and so on [1, 2]. Many researchers have studied the method of the production of hydrogen by the reforming of hydrocarbons like methane, propane, methanol, and kerosene [3-6]. When hydrogen is supplied to PEMFCs by reforming hydrocarbons, it is necessary to remove CO because it poisons the Pt electrode of PEMFCs and decreases their activity for electrochemical reaction. The water-gas shift (WGS) reaction is promising for removing CO from reformer gas $[7,8]$, since it is moderately exothermic reaction $\left(\Delta H_{298}=-41.1 \mathrm{~kJ}\right.$ $\mathrm{mol}^{-1}$ ) and the reaction temperature is easy to control. The equilibrium conversion of $\mathrm{CO}$ is dependent largely on the reaction temperature. Since the WGS reaction is moderately exothermic reaction, lower temperature is favored for higher $\mathrm{CO}$ removal. On the other 
Nishimura et al.

Novel catalytic behavior of $\mathrm{Cu} / \mathrm{Al}_{2} \mathrm{O}_{3}$ catalyst against daily start-up and shut-down (DSS)-like operation in the water gas shift reaction $4 / 46$

hand, from the viewpoint of kinetics, the reactant gases are not active enough to reach the chemical equilibrium at low temperature.

Since daily start-up and shut-down (DSS) operations are envisaged for residential applications of PEMFCs systems, the catalysts for the WGS reaction are sometimes exposed to water and/or oxygen containing atmosphere at low temperatures, and the catalytic activity decreases as a result of oxidation and/or aggregation of active species [9, 10]. For this reason, high sustainability against fluctuation from oxidative to reductive atmospheres in addition to high activity is essential for the catalysts for the WGS reaction. Generally, the activity of copper-based catalysts is higher for this reaction [11-18], but is less stable to oxidant gases than precious metal like $\mathrm{Pt}, \mathrm{Ru}$ and $\mathrm{Au}$. Therefore, it is important to develop highly stable $\mathrm{Cu}$-based catalysts or highly active precious metal catalysts. Recently, various ceria supported metal catalysts have been prepared and used in the WGS reaction. $\mathrm{Cu} / \mathrm{CeO}_{2}$ and $\mathrm{Ni} / \mathrm{CeO}_{2}$ were prepared by the urea coprecipitation-gelation [19], $\mathrm{Pd} / \mathrm{CeO}_{2}$ was prepared by impregnation [20], $\mathrm{Au} / \mathrm{CeO}_{2}$ was prepared by deposition-precipitation [21], and both $\mathrm{Au} / \mathrm{CeO}_{2}$ [22] and $\mathrm{Cu}-\mathrm{Pd} / \mathrm{CeO}_{2}$ catalysts [23] were prepared by the urea coprecipitation-gelation method. However, Zalc et al. [24] reported that a large amount of $\mathrm{H}_{2}$ leads to the irreversible reduction of $\mathrm{CeO}_{2}$ 
Nishimura et al. Novel catalytic behavior of $\mathrm{Cu} / \mathrm{Al}_{2} \mathrm{O}_{3}$ catalyst against daily start-up and shut-down (DSS)-like operation in the water gas shift reaction $5 / 46$

and the catalyst deactivation. $\mathrm{Pt} / \mathrm{TiO}_{2}[25]$ and $\mathrm{Pt} / \mathrm{Al}_{2} \mathrm{O}_{3}$ [26] were promising candidate as the catalysts for low-temperature WGS reaction. Ru was also active for the WGS reaction. $\mathrm{Ru} / \mathrm{V}_{2} \mathrm{O}_{3}$ catalyst was prepared by the reduction of $\mathrm{Ru} / \mathrm{V}_{2} \mathrm{O}_{5}$ at $673 \mathrm{~K}$ in $\mathrm{H}_{2}$ [27] and $\mathrm{Ru} /$ hydroxyapatite catalyst was prepared by deposition-precipitation method [28]. Ternary $\mathrm{Cu} / \mathrm{ZnO} / \mathrm{Al}_{2} \mathrm{O}_{3}$ catalysts have been widely employed commercially since the early $1960 \mathrm{~s}$ in the WGS reaction; the catalyst was usually prepared by coprecipitation method to afford the higher $\mathrm{Cu}$ metal dispersion in the resulting catalyst and, as a consequence, the higher catalytic activity [11]. Coprecipitated $\mathrm{Cu} / \mathrm{ZnO} / \mathrm{Al}_{2} \mathrm{O}_{3}$ catalysts were more sustainable than the impregnated catalysts in the shift reaction [29]. The formation of spinel phase such as $\mathrm{Cu}-\mathrm{Al}, \mathrm{Cu}-\mathrm{Mn}$, and $\mathrm{Cu}-\mathrm{Fe}$ systems [12-14], $\mathrm{CeO}_{2}$ impregnation [15], and $\mathrm{MgO}$ doping [16] have been proposed to improve the stability of $\mathrm{Cu}$-based catalyst. In addition, a variety of preparation methods such as coprecipitation and sol-gel methods have been also investigated $[12,13,16]$. However, further effort to improve the stability of $\mathrm{Cu}$-based catalysts is still necessary. Moreover, it is important to elucidate the mechanism s of improvement of sustainability by the additives and deactivation.

Recently, we reported that an unique and novel behavior and high sustainability of simple binary $\mathrm{Cu} / \mathrm{Al}_{2} \mathrm{O}_{3}$ catalysts, prepared from homogeneous precursors and calcined at 
Nishimura et al. Novel catalytic behavior of $\mathrm{Cu} / \mathrm{Al}_{2} \mathrm{O}_{3}$ catalyst against daily start-up and shut-down (DSS)-like operation in the water gas shift reaction $6 / 46$

low temperature, against the DSS-like operation in the WGS reaction [18]. The $\mathrm{Cu} / \mathrm{Al}_{2} \mathrm{O}_{3}$ catalyst prepared by coprecipitation shows high activity and sustainability even after 50 cycles of DSS-like operation. A mechanism of improvement of sustainability by "in-situ" formation of boehmite $(\mathrm{AlO}(\mathrm{OH}))$ phase is proposed. In this present study, the effects of preparation method and calcination temperature of simple $\mathrm{Cu} / \mathrm{Al}_{2} \mathrm{O}_{3}$ catalyst on their activities for the WGS reaction and sustainability against the DSS-like operation were investigated. We demonstrate that the relationship between the catalytic performance (activity and durability) and the change in structure of $\mathrm{Cu} / \mathrm{Al}_{2} \mathrm{O}_{3}$ catalysts during the reaction by using XRD, TEM, HRTEM, $\mathrm{N}_{2} \mathrm{O}$ decomposition, and $\mathrm{Cu}$ K-edge XAFS techniques in order to demonstrate the important role of "in-situ" formed boehmite in improvement of sustainability against DSS operation.

\section{Experimental}

\subsection{Catalyst preparation}

$\mathrm{Cu} / \mathrm{Al}_{2} \mathrm{O}_{3}$ catalysts $(\mathrm{Cu} / \mathrm{Al}=1 / 2)$ were prepared by coprecipitation (CP-), homogeneous preparation (HP-), sol-gel (SG-) and impregnation (IMP-) methods. The $\mathrm{Cu}$ loading in these $\mathrm{Cu} / \mathrm{Al}_{2} \mathrm{O}_{3}$ catalysts was $5.5 \mathrm{mmol} \mathrm{g}^{-1}$. 
Nishimura et al. Novel catalytic behavior of $\mathrm{Cu} / \mathrm{Al}_{2} \mathrm{O}_{3}$ catalyst against daily start-up and shut-down (DSS)-like operation in the water gas shift reaction $7 / 46$

Co-precipitation method (CP-) $\mathrm{CP}$-catalysts were prepared by coprecipitation, i.e., the aqueous solution of metal nitrates was dropped into aqueous solution of $\mathrm{Na}_{2} \mathrm{CO}_{3}$ with vigorous stirring and the $\mathrm{pH}$ was adjusted at 9 with $\mathrm{NaOH}$. The obtained precipitate was aged at $333 \mathrm{~K}$ for $24 \mathrm{~h}$, filtered, washed with distilled water, and dried at $373 \mathrm{~K}$ for overnight.

Homogeneous precipitation method (HP-) HP-catalysts were prepared by using urea hydrolysis [30-32] as follows: urea was mixed into a solution of metal nitrates at room temperature, and the urea was hydrolyzed by heating the mixture at $363 \mathrm{~K}$. During the hydrolysis of urea, hydroxide ions are generated in the homogeneous solution (Eq. (1)).

$$
\mathrm{CO}\left(\mathrm{NH}_{2}\right)_{2}+3 \mathrm{H}_{2} \mathrm{O} \rightarrow 2 \mathrm{NH}_{4}^{+}+\mathrm{HCO}_{3}^{-}+\mathrm{OH}^{-}
$$

The precipitates were then filtered, washed, and dried in air at $373 \mathrm{~K}$.

Sol-gel method (SG-) SG-catalysts were prepared by the citrate sol-gel method $[33,34]$.

Two kinds of aqueous solutions of copper and aluminum nitrate were treated with an excess amount of citric acid and ethylene glycol and then each solution was mixed. This mixture was evaporated at $348 \mathrm{~K}$ to make a sol of the organometallic complex.

Impregnation method (IMP-) IMP-catalysts were prepared by an impregnation method using $\gamma-\mathrm{Al}_{2} \mathrm{O}_{3}\left(164 \mathrm{~m}^{2} \mathrm{~g}^{-1}\right.$, JRC-ALO-8) and $\mathrm{Cu}$ nitrate solution. IMP-Cu/AlO(OH) was 
Nishimura et al. Novel catalytic behavior of $\mathrm{Cu} / \mathrm{Al}_{2} \mathrm{O}_{3}$ catalyst against daily start-up and shut-down (DSS)-like operation in the water gas shift reaction

also prepared by impregnation and calcined at $823 \mathrm{~K}$ in air for $3 \mathrm{~h}$. $\mathrm{AlO}(\mathrm{OH})\left(265 \mathrm{~m}^{2} \mathrm{~g}^{-1}\right.$, Wako) was used as the support and impregnated with $\mathrm{Cu}$ nitrate aqueous solution. The $\mathrm{Cu}$ loading on IMP-Cu/AlO(OH) is similar to those of $\mathrm{Cu} / \mathrm{Al}_{2} \mathrm{O}_{3}$ catalysts.

The catalysts were obtained by calcining the precipitates at $573-1173 \mathrm{~K}$ in air (abbreviated as CP- $X$, where $X$ is the calcination temperature).

\subsection{Characterization}

The structure of prepared catalyst was studied by using XRD, TEM, $\mathrm{H}_{2}-\mathrm{TPR}, \mathrm{N}_{2}$ adsorption and $\mathrm{N}_{2} \mathrm{O}$ decomposition methods.

XRD patterns of the catalysts were recorded using a Rigaku Rint 1000 instrument, with mono-chromatized $\mathrm{Cu} \mathrm{K} \alpha$ radiation $(\lambda=0.154 \mathrm{~nm})$ at $40 \mathrm{kV}$ and $20 \mathrm{~mA}$. The diffraction pattern was identified by comparing with those in the JCPDS (Joint Committee of Powder Diffraction Standards) database. The mean crystallite size was determined according to the Scherrer equation. The change in the morphology of the catalyst was observed by transmission electron microscope (TEM). TEM, high-resolution TEM and energy dispersive X-ray spectroscopy (EDS) measurements were performed with Hitachi H-7100 and JEOL JEM-2100F. The $\mathrm{H}_{2}$-TPR profiles recorded using an Ohkura BP-2 
Nishimura et al. Novel catalytic behavior of $\mathrm{Cu} / \mathrm{Al}_{2} \mathrm{O}_{3}$ catalyst against daily start-up and shut-down (DSS)-like operation in the water gas shift reaction $9 / 46$

instrument were used for determination of $\mathrm{H}_{2}$ consumption for reduction of $\mathrm{Cu}$ species in $\mathrm{Cu} / \mathrm{Al}_{2} \mathrm{O}_{3}$ catalysts. The fresh catalysts were oxidized with $\mathrm{O}_{2}$ at $573 \mathrm{~K}$ for $1 \mathrm{~h}$ prior to determination of the TPR profile. After the reduction at $523 \mathrm{~K}$ and the DSS-like operation, the catalysts were cooled to room temperature in $\mathrm{N}_{2}$. The catalysts were mounted in quartz tubes in air and heated in $5 \mathrm{vol} . \% \mathrm{H}_{2}$ diluted with argon without any pretreatment at a heating rate of $10 \mathrm{~K} \mathrm{~min}^{-1}$. The gas was purified by passing through both $13 \mathrm{X}$ molecular sieves for removal of trace amount of water and $\mathrm{MnO}_{2}$ for removal of trace amount of oxygen. The change in the $\mathrm{H}_{2}$ concentration was monitored by a thermal conductivity detector (TCD). Since water is formed during the reduction process, the effluent gas from the reactor was dried over 5A molecular sieves before entering the TCD. The amount of consumed $\mathrm{H}_{2}$ was quantified by a calibration curve method. BET surface areas of samples were determined by using $\mathrm{N}_{2}$ adsorption isotherm at $77 \mathrm{~K}$ with COULTER SA3100. The copper metal surface areas were determined by $\mathrm{N}_{2} \mathrm{O}$ decomposition method as reported by Evans et al. [35], assuming a reaction stoichiometry of two $\mathrm{Cu}$ atoms per oxygen atom and a $\mathrm{Cu}$ surface density of $1.68 \times 10^{19} \mathrm{Cu}$ atom $\mathrm{m}^{-2}$. Prior to the measurement, sample was

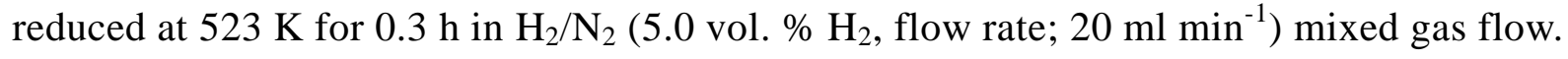


Nishimura et al. Novel catalytic behavior of $\mathrm{Cu} / \mathrm{Al}_{2} \mathrm{O}_{3}$ catalyst against daily start-up and shut-down (DSS)-like operation in the water gas shift reaction $10 / 46$

2.3 Catalytic reactions and analyses of the products

The WGS reaction was carried out using a fixed bed reactor at atmospheric pressure with $\mathrm{CO} / \mathrm{CO}_{2} / \mathrm{H}_{2} \mathrm{O} / \mathrm{H}_{2}(7.3 / 7.3 / 27.2 / 58.3)$ mixed gas at $473 \mathrm{~K}$. Prior to the WGS reaction, $0.2 \mathrm{~g}$ of the catalysts were reduced with 5 vol. $\% \mathrm{H}_{2}$ diluted with nitrogen at $523 \mathrm{~K}$ for 0.5

h. The products were analyzed using two on-line gas chromatographs (GC). A GC with packed Molecular Sieve 5A column, Ar carrier gas and TCD were used to analyze $\mathrm{H}_{2}$. Another GC with packed Porapak-Q column, $\mathrm{N}_{2}$ carrier gas and FID with methanizer were used to analyze $\mathrm{CO}$ and $\mathrm{CO}_{2}$. The conversion of $\mathrm{CO}$ was quantified by a calibration curve method and the following equation (Eq. (2)).

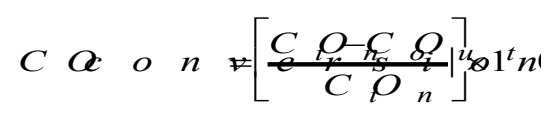

As a DSS-like operation, steam treatment in $\mathrm{H}_{2} \mathrm{O} / \mathrm{N}_{2}$ (25.1/74.9) was repeated over the temperature range of 323-473 K (Fig. 1). After this DSS-like operation, the WGS reaction was carried out again and $\mathrm{CO}$ conversion was compared with that of fresh catalyst. A commercial $\mathrm{Cu} / \mathrm{ZnO} / \mathrm{Al}_{2} \mathrm{O}_{3}$ catalyst, $\mathrm{MDC}-7$ ( $\mathrm{Cu}$ loading, estimated by $\mathrm{XRF}$, was almost similar to those of prepared $\mathrm{Cu}-\mathrm{Al}-\mathrm{Ox}$ catalysts, $5.4 \mathrm{mmolg}^{-1}$.), was used as a reference.

\subsection{In-situ time-resolved XAFS}


Nishimura et al. Novel catalytic behavior of $\mathrm{Cu} / \mathrm{Al}_{2} \mathrm{O}_{3}$ catalyst against daily start-up and shut-down (DSS)-like operation in the water gas shift reaction $11 / 46$

In-situ time-resolved $\mathrm{Cu} K$-edge X-ray absorption spectra (XAS) were measured on the beam line BL01B1 at SPring-8 of the Japan Synchrotron Radiation Research Institute (Proposal No. 2007B1123 and 2008A1147), Japan in a transmission mode at room temperature by using two ion chambers. The storage ring was operated at $8 \mathrm{GeV}$ with injection currents of $100 \mathrm{~mA}$. $\mathrm{Si}(111)$ single crystal is used to obtain a monochromatic X-ray beam. The wafer of the sample diluted with boron nitride (Wako) was mounted in an in-situ flow cell designed by Suzuki and Nomura [36]. Cu K-edge XAFS spectra were measured in the Quick-XAFS (QXAFS) mode with a time resolution of $60 \mathrm{~s} \mathrm{spectrum}^{-1}$ (8723-10362 eV). Scheme of in-situ experiment was shown in Fig. 2. First the catalysts were reduced with 5 vol. $\% \mathrm{H}_{2}$ diluted with helium from room temperature to $633 \mathrm{~K}$ with a ramping rate of $5 \mathrm{~K} \mathrm{~min}^{-1}$. Then, the WGS reaction was carried out with $\mathrm{CO} / \mathrm{CO}_{2} / \mathrm{H}_{2} \mathrm{O} / \mathrm{H}_{2}$ (7.3/7.3/27.2/58.3) mixed gas at $473 \mathrm{~K}$ for $0.5 \mathrm{~h}$. Next, as a DSS-like operation, steam treatment in $\mathrm{H}_{2} \mathrm{O} / \mathrm{He}(25.1 / 74.9)$ was carried out over the temperature range of $323-473 \mathrm{~K}$. After this DSS-like operation, the WGS reaction was carried out again. Data are analyzed by means of the REX2000 program (Version: 2.5.7; Rigaku Corp.). The oscillation is normalized by the edge height around $70-100 \mathrm{eV}$ higher than the threshold. Identification of the number of phases was achieved by factor analysis of observed XANES spectra. 
Nishimura et al. Novel catalytic behavior of $\mathrm{Cu} / \mathrm{Al}_{2} \mathrm{O}_{3}$ catalyst against daily start-up and shut-down (DSS)-like operation in the water gas shift reaction $12 / 46$

Factor analysis of a series of XANES spectra were performed with Specfit ver. 2.12 for

MS-DOS. References spectra of $\mathrm{Cu}$ metal, $\mathrm{Cu}_{2} \mathrm{O}$ and $\mathrm{CuO}$ were then used in a least-squares fitting procedure of the time-resolved spectra to determine the fraction of each phase present.

\section{Results and discussion}

\subsection{Effect of calcination temperature on the initial activity}

Fig. 3 shows the XRD patterns of $\mathrm{CP}-$ and $\mathrm{IMP}-\mathrm{Cu} / \mathrm{Al}_{2} \mathrm{O}_{3}$ before and after calcination at various temperatures. The diffraction lines of hydrotalcite-like compound (JCPDS 89-0460) were observed in the XRD patterns of the $\mathrm{CP}-\mathrm{Cu} / \mathrm{Al}_{2} \mathrm{O}_{3}$ after drying at $373 \mathrm{~K}$ (Fig. 3 A (a)). The intensity of the diffraction lines of $\mathrm{CuO}$ (JCPDS 48-1548) and $\mathrm{CuAl}_{2} \mathrm{O}_{4}$ spinel phase (JCPDS 73-1958) increased with increasing the calcination temperature. The XRD pattern of CP-1173 catalysts showed diffraction lines of well crystallized $\mathrm{CuAl}_{2} \mathrm{O}_{4}$ spinel phase and weak lines of $\mathrm{CuO}$, suggesting that the most part of $\mathrm{Cu}^{2+}$ was dispersed uniformly in a spinel structure. In the case of IMP-Cu/ $\mathrm{Al}_{2} \mathrm{O}_{3}$ catalysts, the calcination up to $973 \mathrm{~K}$ did not cause the formation of $\mathrm{CuAl}_{2} \mathrm{O}_{4}$ spinel phase crystallite.

Above $1023 \mathrm{~K}$, strong diffraction lines of $\mathrm{CuO}$ together with lines of spinel $\mathrm{CuAl}_{2} \mathrm{O}_{4}$ 
Nishimura et al. Novel catalytic behavior of $\mathrm{Cu} / \mathrm{Al}_{2} \mathrm{O}_{3}$ catalyst against daily start-up and shut-down (DSS)-like operation in the water gas shift reaction $13 / 46$

phase were found. The intensity of the diffraction lines of $\mathrm{CuAl}_{2} \mathrm{O}_{4}$ spinel phase increased with increasing the calcination temperature. The intensity and width of the lines of $\mathrm{CuO}$ on IMP-1173 was much stronger and narrower than those on CP-1173, indicating that the crystallite size of $\mathrm{CuO}$ on IMP-1173 was larger than that on CP-1173.

TPR profiles of $\mathrm{CP}$ - and IMP-Cu/ $\mathrm{Al}_{2} \mathrm{O}_{3}$ catalysts calcined at various temperatures are shown in Fig. 4. The numbers by peaks are the amount of $\mathrm{H}_{2}$ consumed $\left(\mathrm{mmol} \mathrm{g}^{-1}\right)$. Although the reduction of bulk $\gamma-\mathrm{Al}_{2} \mathrm{O}_{3}$ is thermodynamically feasible at high temperatures, $\gamma-\mathrm{Al}_{2} \mathrm{O}_{3}$ showed no distinct peak of the reduction up to $800 \mathrm{~K}$ (data not shown). IMP-823 catalyst showed a single $\mathrm{H}_{2}$ consumption peak at $560 \mathrm{~K}$ with a small shoulder around $580 \mathrm{~K}$, which is assignable to reduction of $\mathrm{Cu}^{2+}$ in bulk $\mathrm{CuO}$ to $\mathrm{Cu}^{0}$ with a large distribution of particle size [14, 37-39]. When the calcination temperature increased up to $1023 \mathrm{~K}$, the $\mathrm{H}_{2}$ consumption peak shifts to slightly lower temperature (ca. 510 and $530 \mathrm{~K}$ ) and the amount of $\mathrm{H}_{2}$ consumed slightly decreased. When the IMP-Cu/ $\mathrm{Al}_{2} \mathrm{O}_{3}$ catalysts were calcined above $1023 \mathrm{~K}$, a small $\mathrm{H}_{2}$ consumption peaks appeared at $510 \mathrm{~K}$ and around $730 \mathrm{~K}$. These two peaks are assignable to the reduction of highly dispersed $\mathrm{CuO}$ and $\mathrm{CuAl}_{2} \mathrm{O}_{4}$ spinel phase, respectively [14]. The amount of $\mathrm{H}_{2}$ consumed around $560 \mathrm{~K}$ decreased with increasing the calcination temperature. These 
Nishimura et al. Novel catalytic behavior of $\mathrm{Cu} / \mathrm{Al}_{2} \mathrm{O}_{3}$ catalyst against daily start-up and shut-down (DSS)-like operation in the water gas shift reaction $14 / 46$

results indicate that bulk $\mathrm{CuO}$ was transformed to highly dispersed $\mathrm{CuO}$ and $\mathrm{CuAl}_{2} \mathrm{O}_{4}$ spinel phase by calcination at high temperature. CP-823 and 873 catalysts show two $\mathrm{H}_{2}$ consumption peaks. CP-973 showed a $\mathrm{H}_{2}$ consumption peak at $525 \mathrm{~K}$ with small peak at $680 \mathrm{~K}$, and the former peak shifted to slightly lower temperature by increasing the calcination temperature up to $973 \mathrm{~K}$. Luo et al. reported that the reduction temperature of highly dispersed $\mathrm{CuO}$ species was lower than that of bulk $\mathrm{CuO}$ species using $\mathrm{H}_{2}-\mathrm{TPR}$ combined with in-situ XRD [40]. It appears that the shift of $\mathrm{H}_{2}$ consumption peak to lower temperature is due to the improvement of the dispersion of $\mathrm{CuO}$ species. The $\mathrm{H}_{2}$ consumption peak temperature of CP-973 (525 K) was lower than that of IMP-973 (560 $\mathrm{K})$, suggesting that the dispersion of $\mathrm{CuO}$ on CP-973 was higher than that on IMP-973. These results correspond with the copper metal surface area $\left(\mathrm{Cu}^{0}\right.$ surface area) (vide infra). CP-1073 and 1173 showed two $\mathrm{H}_{2}$ consumption peaks around $490 \mathrm{~K}$ and broad peak around $690 \mathrm{~K}$. The amount of $\mathrm{H}_{2}$ consumption around $490 \mathrm{~K}$ of $\mathrm{CP}-1173$ is smaller than that at $525 \mathrm{~K}$ of $\mathrm{CP}-973$. This suggests that the amount of highly dispersed $\mathrm{CuO}$ species over CP-1173 is smaller than that of CP-973.

Fig. 5 shows the activities in the WGS reaction and $\mathrm{Cu}^{0}$ surface area determined by $\mathrm{N}_{2} \mathrm{O}$ pulse method of CP- and IMP-Cu/ $\mathrm{Al}_{2} \mathrm{O}_{3}$ catalysts calcined at various temperatures. In 
Nishimura et al. Novel catalytic behavior of $\mathrm{Cu} / \mathrm{Al}_{2} \mathrm{O}_{3}$ catalyst against daily start-up and shut-down (DSS)-like operation in the water gas shift reaction $15 / 46$

the case of $\mathrm{CP}-\mathrm{Cu} / \mathrm{Al}_{2} \mathrm{O}_{3}$ catalysts, $\mathrm{CO}$ conversion increased up to $973 \mathrm{~K}$ and then remarkably decreased. The change in $\mathrm{Cu}^{0}$ surface area against the calcination temperature correlates with the change in $\mathrm{CO}$ conversion, suggesting $\mathrm{Cu}^{0}$ as the active species. On the basis of TPR profiles, it is likely that the amount of $\mathrm{CuO}$ particles can be reduced at lower temperature affected to the catalytic activity. HP- and SG-catalysts showed almost similar change in the XRD pattern, $\mathrm{CO}$ conversion, and $\mathrm{Cu}^{0}$ surface area (see Figs. $\mathrm{S} 1$ and $\mathrm{S} 2$ ). In the case of IMP-Cu/ $\mathrm{Al}_{2} \mathrm{O}_{3}$ catalysts, IMP-973 showed the highest $\mathrm{CO}$ conversion among IMP- $\mathrm{Cu} / \mathrm{Al}_{2} \mathrm{O}_{3}$ catalysts tested, whereas the magnitude of the changes in $\mathrm{Cu}^{0}$ surface area was not very large. These results suggest that the formation of $\mathrm{CuAl}_{2} \mathrm{O}_{4}$ spinel phase by calcination at high temperatures (above $1023 \mathrm{~K}$ ) affects the catalytic activity.

\subsection{Effect of calcination temperature on the sustainability}

Both CP- and IMP-Cu/ $/ \mathrm{Al}_{2} \mathrm{O}_{3}$ catalysts were calcined at 823 and $1073 \mathrm{~K}$ and the effect of the DSS-like operation on the sustainability for the WGS reaction was tested. Time course of the WGS reaction before and after 10 cycles of DSS-like operation over CP- and IMP- $\mathrm{Cu} / \mathrm{Al}_{2} \mathrm{O}_{3}$ catalysts together with a commercial $\mathrm{Cu} / \mathrm{ZnO} / \mathrm{Al}_{2} \mathrm{O}_{3}$ catalyst (MDC-7) are shown in Fig. 6. Before DSS-like operation, $\mathrm{Cu} / \mathrm{Al}_{2} \mathrm{O}_{3}$ catalysts calcined at 
Nishimura et al.

Novel catalytic behavior of $\mathrm{Cu} / \mathrm{Al}_{2} \mathrm{O}_{3}$ catalyst against daily start-up and shut-down (DSS)-like operation in the water gas shift reaction $16 / 46$

$1073 \mathrm{~K}$ showed higher $\mathrm{CO}$ conversion those calcined at $823 \mathrm{~K}$. The commercial $\mathrm{Cu} / \mathrm{ZnO} / \mathrm{Al}_{2} \mathrm{O}_{3}$ catalyst showed higher activity than $\mathrm{Cu} / \mathrm{Al}_{2} \mathrm{O}_{3}$ catalysts. The activities of CP-1073, IMP-823, IMP-1073, and the commercial $\mathrm{Cu} / \mathrm{ZnO} / \mathrm{Al}_{2} \mathrm{O}_{3}$ catalyst remarkably decreased after DSS-like operation. Surprisingly, the activity of CP-823 was remarkably improved by DSS-like operation, and moreover the activity of this catalyst was almost similar to that of the commercial ternary $\mathrm{Cu} / \mathrm{ZnO} / \mathrm{Al}_{2} \mathrm{O}_{3}$ catalyst.

Fig. 7 shows the activities and BET surface areas of $\mathrm{Cu} / \mathrm{Al}_{2} \mathrm{O}_{3}$ catalysts calcined at 823 and $1073 \mathrm{~K}$, together with a commercial $\mathrm{Cu} / \mathrm{ZnO} / \mathrm{Al}_{2} \mathrm{O}_{3}$ catalyst (MDC-7), in the WGS reaction before and after the DSS-like operation. The BET surface areas of $\mathrm{Cu} / \mathrm{Al}_{2} \mathrm{O}_{3}$ catalysts calcined at $1073 \mathrm{~K}$ and MDC-7 were almost constant before and after the DSS-like operation in spite of the preparation method. In the case of HP-1073, CO conversion decreased slightly after the first DSS-like operation and decreased drastically after 10 cycles. CP-1073, SG-1073, and IMP-1073 showed similar behavior, indicating that the spinel $\mathrm{CuAl}_{2} \mathrm{O}_{4}$ phase cannot prevent deactivation during the DSS-like operation. IMP-823 showed significant deactivation immediately after the first DSS-like operation, suggesting that $\mathrm{Cu}$ metal was immediately oxidized and/or aggregated by steam. The activity of MDC-7 also decreased drastically with increase in the number of cycles of 
Nishimura et al. Novel catalytic behavior of $\mathrm{Cu} / \mathrm{Al}_{2} \mathrm{O}_{3}$ catalyst against daily start-up and shut-down (DSS)-like operation in the water gas shift reaction $17 / 46$

DSS-like operation. By contrast, HP-823 and SG-823 exhibited improved CO conversion with increasing number of cycles of DSS-like operation. In the case of CP-823, CO conversion increased up to 10 cycles of DSS-like operation and maintained a high level even after 50 cycles. Although the initial activities of CP-823, HP-823, and SG-823 catalysts were lower than those of CP-1073, HP-1073, and SG-1073, respectively, after 10 cycles of DSS-like operation reversal of the relative activities was found. BET surface areas of HP-823 and SG-823 catalysts increased up to 10 cycles of DSS-like operation. In the case of CP-823, BET surface area increased up to 10 cycles of DSS-like operation and slightly decreased after 50 cycles. This suggests that the change in the structure of $\mathrm{Cu} / \mathrm{Al}_{2} \mathrm{O}_{3}$ catalyst calcined at $823 \mathrm{~K}$ during the DSS-like operation affects the catalytic activity. CP-823 catalyst showed the highest activity among the $\mathrm{Cu} / \mathrm{Al}_{2} \mathrm{O}_{3}$ catalysts tested. These results clearly demonstrate that the catalytic activity and sustainability against DSS-like operation are strongly affected by not only preparation method but also calcination temperature. The activities of CP-823, HP-823, and SG-823 catalysts were improved by DSS-like operation, suggesting that the homogeneity of the precursor has an important role in the preparation of highly sustainable catalyst. 
Nishimura et al. Novel catalytic behavior of $\mathrm{Cu} / \mathrm{Al}_{2} \mathrm{O}_{3}$ catalyst against daily start-up and shut-down (DSS)-like operation in the water gas shift reaction $18 / 46$

\subsection{Effect of DSS operation on the structure}

Fig. 8 shows the XRD patterns of $\mathrm{Cu} / \mathrm{Al}_{2} \mathrm{O}_{3}$ catalysts calcined at 823 and $1073 \mathrm{~K}$ after 10 cycles of DSS-like operation. CP-823, HP-823, and SG-823 reduced at $523 \mathrm{~K}$ showed the diffraction lines characteristic of $\mathrm{Cu}$ metal. The crystalline sizes of $\mathrm{Cu}$ metal in the catalysts were estimated to be 13 (CP-), 22 (HP-) and 23 (SG-) nm. After 10 cycles of DSS-like operation, the intensity and width of the diffraction lines of $\mathrm{Cu}$ metal were almost similar to those before the DSS-like operation, indicating that the sizes of $\mathrm{Cu}$ metal particles before DSS-like operation were almost similar to those after 10 cycles of DSS-like operation. The order of the crystalline sizes of $\mathrm{Cu}$ metal did not correspond with that of the activity. Many researchers have proposed that the activity of $\mathrm{Cu}$-based catalyst depends on the $\mathrm{Cu}$ metal surface area $[11,12,14,16,41,42]$. For example, the Cu metal surface areas of $\mathrm{HP}-\mathrm{Cu} / \mathrm{ZnO}, \mathrm{HP}-\mathrm{Cu} / \mathrm{ZnO} / \mathrm{Al}_{2} \mathrm{O}_{3}$, and $\mathrm{HP}-\mathrm{Cu} / \mathrm{ZnO} / \mathrm{MgO}$ catalyst well correlated with the activities $[16,41]$. Moreover, the catalytic activity correlates roughly with the $\mathrm{Cu}$ metal surface area after DSS-like operation (Fig. S3). Hence, an aggregation of a part of $\mathrm{Cu}$ metal may be one of the reasons for decreased activity for the WGS reaction resulting from DSS-like operation. In the case of CP-, HP-, and SG-823 (Figs. 8 (a), (b) and (c)), diffraction lines of boehmite $(\mathrm{AlO}(\mathrm{OH}))$ phase (JCPDS 21-1307) are 
Nishimura et al. Novel catalytic behavior of $\mathrm{Cu} / \mathrm{Al}_{2} \mathrm{O}_{3}$ catalyst against daily start-up and shut-down (DSS)-like operation in the water gas shift reaction $19 / 46$

apparent. On the contrary, no diffraction line of boehmite was obtained in the XRD pattern of IMP-823 (Fig. 8 (d)). Moreover, $\mathrm{Cu} / \mathrm{Al}_{2} \mathrm{O}_{3}$ catalysts calcined at $1073 \mathrm{~K}$, which are remarkably deactivated by DSS-like operation as shown in Fig. 7, and Fig. 8(B) showed no diffraction lines of boehmite phase after 10 cycles of DSS-like operation in spite of the preparation method. Furthermore, in spite of calcination temperature, only the catalysts having diffraction lines of boehmite phase after 10 cycles of DSS-like operation indicated a high sustainability against DSS-like operations (Fig. S4). These results strongly indicate that boehmite has an important role in the sustainability against DSS operation. However, in the case of $\mathrm{Cu} / \mathrm{AlO}(\mathrm{OH}), \mathrm{CO}$ conversion drastically decreased after 10 cycles of DSS-like operation (CO conversion decreased from $19 \%$ to $4 \%$ ), suggesting that both close contact between $\mathrm{Cu}$ species and $\mathrm{AlO}(\mathrm{OH})$ is necessary to inhibit the deactivation during DSS operation. Fig. 9 shows the change in XRD patterns of CP- and IMP-Cu/ $\mathrm{Al}_{2} \mathrm{O}_{3}$ calcined at $823 \mathrm{~K}$ against the cycles of DSS-like operation. In the case of IMP-823, no significant change in XRD pattern was observed. In contrast, in the case of CP-823, the diffraction lines of boehmite phase grew with the number of cycles of DSS-like operation.

The morphology of CP-823 and IMP-823 catalysts before and after DSS-like operation was investigated by TEM (Fig. 10). In the case of IMP-823 catalyst, no 
Nishimura et al. Novel catalytic behavior of $\mathrm{Cu} / \mathrm{Al}_{2} \mathrm{O}_{3}$ catalyst against daily start-up and shut-down (DSS)-like operation in the water gas shift reaction $20 / 46$

significant change in the structure (rod-like crystals of $\gamma-\mathrm{Al}_{2} \mathrm{O}_{3}$ ) was observed after DSS-like operation (Fig. 10 (c) and (d)). In contrast, the TEM image of CP-823 catalyst after 50 cycles of DSS-like operation (Fig. 10 (b)) shows the formation of needle-like crystals, which is typical morphology for boehmite [42]. Furthermore, a number of small $\mathrm{Cu}$ species (ca. $15 \mathrm{~nm}$ ) which was covered with boehmite looks like "bird's nest" together with a few large $\mathrm{Cu}$ metal particles (ca. $30 \mathrm{~nm}$ ) was observed. This suggests that a few $\mathrm{Cu}$ metal particles were aggregated during DSS operation and the others which were covered with boehmite were inhibited from aggregation. IMP-Cu/AlO $(\mathrm{OH})$ before and after 10 cycles of DSS-like operation showed needle-like crystals of boehmite whose size was much larger (Fig. S5) than that was formed on CP-823 after DSS-like operation (Fig. 10 (b)). The mean particle size of $\mathrm{Cu}$ metal was estimated to $36.0 \mathrm{~nm}$ from XRD patterns after 10 cycles of DSS-like operation and was much larger than that of CP-823.

According to above results, it can be concluded that inhibition of aggregation of $\mathrm{Cu}$ metal by "in-situ" formation of a small size of boehmite results in high sustainability against DSS operation. 
Nishimura et al. Novel catalytic behavior of $\mathrm{Cu} / \mathrm{Al}_{2} \mathrm{O}_{3}$ catalyst against daily start-up and shut-down (DSS)-like operation in the water gas shift reaction $21 / 46$

Fig. 11 shows TPR profiles of CP-823 and IMP-823 catalysts before and after a number of cycles of DSS-like operation. Freshly prepared IMP-823 catalyst shows a single $\mathrm{H}_{2}$ consumption peak at $560 \mathrm{~K}$ with a small shoulder at $580 \mathrm{~K}$ (Fig. $11 \mathrm{~B}$ (a)), which is assignable to reduction of $\mathrm{Cu}^{2+}$ in bulk $\mathrm{CuO}$ to $\mathrm{Cu}^{0}$ with a large distribution of particle size [14]. After reduction at $523 \mathrm{~K}$, the $\mathrm{H}_{2}$ consumption peak shifts to lower temperature (ca. $505 \mathrm{~K}$ ) with a shoulder peak (ca. $470 \mathrm{~K}$ ) (Fig. 11 B (b)). After 10 cycles of DSS-like operation, the amount of $\mathrm{H}_{2}$ consumed is much smaller than that after the reduction. It seems that the $\mathrm{H}_{2}$ consumption is caused by reduction of surface layer of or interfacial copper species oxidized during exposure to air at room temperature. When this sample was oxidized at $573 \mathrm{~K}, \mathrm{H}_{2}$ consumption peak around $525 \mathrm{~K}$ with a shoulder peak (ca. 470 $\mathrm{K}$ ) is observed and the amount of $\mathrm{H}_{2}$ consumed is recovered by ca. $85 \%$ of the fresh catalyst (Fig. 11 B (c) thin line). This suggests that a most part of core of copper metal particles on IMP-823 was oxidized at $573 \mathrm{~K}$. On the basis of these results, it appears that the copper metal particles on IMP-823 treated after 10 cycles of DSS-like operation is decorated with oxidized copper species. CP-823 catalyst shows two $\mathrm{H}_{2}$ consumption peaks at 540 and $615 \mathrm{~K}$ (Fig. $11 \mathrm{~A}$ (a)). After reduction at $523 \mathrm{~K}$, the $\mathrm{H}_{2}$ consumption peak shifts to lower temperature (ca. $520 \mathrm{~K}$ ) (Fig. $11 \mathrm{~A}(\mathrm{~b})$ ). After the 10 cycles of DSS-like operation, 
Nishimura et al. Novel catalytic behavior of $\mathrm{Cu} / \mathrm{Al}_{2} \mathrm{O}_{3}$ catalyst against daily start-up and shut-down (DSS)-like operation in the water gas shift reaction $22 / 46$

the $\mathrm{H}_{2}$ consumption peak also shifts to lower temperature (ca. $490 \mathrm{~K}$ ) (Fig. $11 \mathrm{~A}$ (c)). The consumption of $\mathrm{H}_{2}$ is almost similar to that of the catalyst reduced at $523 \mathrm{~K}$. Agrell et al. reported that the peak of $\mathrm{H}_{2}$-TPR shifted ca. $40 \mathrm{~K}$ toward lower temperature due to improvement the dispersion of copper on $\mathrm{Cu} / \mathrm{ZnO} / \mathrm{Al}_{2} \mathrm{O}_{3}$ [43]. Therefore, these results suggest that a part of copper species on CP-823 dispersed during the DSS-like operation up to 10 cycles. This may result in the increasing in the boundary between copper species and aluminum compounds. When this sample was oxidized at $573 \mathrm{~K}, \mathrm{CP}-823$ catalyst shows $\mathrm{H}_{2}$ consumption peak at $515 \mathrm{~K}$ with two shoulder peaks (ca. 470 and $500 \mathrm{~K}$ ) (Fig. $11 \mathrm{~A}(\mathrm{c})$ thin line). The ratio of the amount of $\mathrm{H}_{2}$ consumed before and after oxidation at $573 \mathrm{~K}(2.7 / 4.3=0.63)$ is much larger than that of IMP-823 $(0.5 / 4.6=0.11)$, indicating that the amount of copper species, which can be easily oxidized and reduced at low temperature, on CP-823 is much larger than that on IMP-823 after 10 cycles of DSS-like operation. These results also suggest that the boundary between copper species and aluminum compounds on CP-823 is much larger than that of IMP-823. Interestingly, the consumption of $\mathrm{H}_{2}$ is constant up to 20 cycles of DSS-like operation (Fig. 11 A (d)), suggesting that aggregation of $\mathrm{Cu}$ metal particles does not occur during the DSS-like operation. This is cause by the inhibition of aggregation of $\mathrm{Cu}$ metal particles by boehmite 
Nishimura et al. Novel catalytic behavior of $\mathrm{Cu} / \mathrm{Al}_{2} \mathrm{O}_{3}$ catalyst against daily start-up and shut-down (DSS)-like operation in the water gas shift reaction $23 / 46$

phase formed "in-situ" during the DSS operation.

\subsection{In-situ time-resolved Cu K-edge XAFS}

In-situ time-resolved $\mathrm{Cu}$ K-edge XANES spectra were measured to investigate the redox behavior of $\mathrm{Cu}$ species under reaction and DSS-like conditions. A factor analysis of the $\mathrm{Cu}$ K-edge XANES spectra revealed that three primary components were necessary to reconstruct the experimental XANES spectra. $\mathrm{Cu}^{0}, \mathrm{Cu}_{2} \mathrm{O}$, and $\mathrm{CuO}$ were used as three probable reference compounds. Fig. 12 shows the change in $\mathrm{Cu}$ K-edge XANES spectra of CP-823 and IMP-823 during the DSS-like operation. Both CP-823 and IMP-823 show following behavior; $\mathrm{Cu}$ K-edge XANES spectra of both CP-823 and IMP-823 are similar to $\mathrm{Cu}$ metal (Fig. S6) under the WGS reaction condition before DSS-like operation. Then XANES spectra of CP-823 and IMP-823 are gradually changed, suggesting that a part of $\mathrm{Cu}$ metal was oxidized to $\mathrm{Cu}_{2} \mathrm{O}$ and/or $\mathrm{CuO}$ (Fig. S6) under DSS-like operation. XANES spectra of CP-823 and IMP-823 after the 2nd WGS reaction after DSS-like operation are also similar to $\mathrm{Cu}$ metal, suggesting that most part of $\mathrm{Cu}$ species is present as $\mathrm{Cu}$ metal. To evaluate the fraction for each $\mathrm{Cu}$ species as a function of time, the spectra were analyzed by a liner combination method with $\mathrm{Cu}$ metal, $\mathrm{Cu}_{2} \mathrm{O}$, and $\mathrm{CuO}$ spectra as references. The 
Nishimura et al. Novel catalytic behavior of $\mathrm{Cu} / \mathrm{Al}_{2} \mathrm{O}_{3}$ catalyst against daily start-up and shut-down (DSS)-like operation in the water gas shift reaction $24 / 46$

evolutions of the phase composition of CP-823 and IMP-823 catalysts are shown in Fig.

13. For CP-823, a most part of copper is present as $\mathrm{Cu}^{0}$ under the WGS reaction condition.

When a reaction mixture $\left(\mathrm{CO} / \mathrm{CO}_{2} / \mathrm{H}_{2} \mathrm{O} / \mathrm{H}_{2}=7.3 / 7.3 / 27.2 / 58.3\right)$ was changed to a mixture

of $\mathrm{H}_{2} \mathrm{O} / \mathrm{He}(25.1 / 74.9)$, a part of $\mathrm{Cu}^{0}$ was oxidized to $\mathrm{Cu}(\mathrm{I})$ and $\mathrm{Cu}(\mathrm{II})$. The fraction of $\mathrm{Cu}(\mathrm{I})$ increased with increasing the temperature and reached ca. $40 \%$. After a mixture of $\mathrm{H}_{2} \mathrm{O} / \mathrm{He}$ has been switched to the reaction mixture at $473 \mathrm{~K}$, a rapid reduction of $\mathrm{Cu}(\mathrm{I})$ proceeded. In the case of IMP-823, a most part of copper is present as $\mathrm{Cu}^{0}$ under the WGS reaction condition. When a reaction mixture was changed to a mixture of $\mathrm{H}_{2} \mathrm{O} / \mathrm{He}$, a small part of $\mathrm{Cu}^{0}$ was oxidized to $\mathrm{Cu}(\mathrm{I})$ and $\mathrm{Cu}(\mathrm{II})$ oxides. The fraction of $\mathrm{Cu}(\mathrm{I})$ slightly increased with increasing the temperature and reached ca. $12 \%$. After a mixture of $\mathrm{H}_{2} \mathrm{O} / \mathrm{He}$ has been switched to the reaction mixture at $473 \mathrm{~K}$, a rapid reduction of $\mathrm{Cu}(\mathrm{I})$ proceeded. These results indicate that the amount of copper species, which can be easily oxidized and reduced at low temperature, on CP-823 is much larger than that on IMP-823. This result corresponds with $\mathrm{H}_{2}$-TPR results.

3.6. High sustainability of CP-823 against DSS operation Surprisingly, the activity of CP-823 was greatly improved by DSS-like operation as 
Nishimura et al. Novel catalytic behavior of $\mathrm{Cu} / \mathrm{Al}_{2} \mathrm{O}_{3}$ catalyst against daily start-up and shut-down (DSS)-like operation in the water gas shift reaction $25 / 46$

shown in Figs. 6 and 7. At the initial stage, the sustainability of this catalyst was superior to that of the commercial ternary $\mathrm{Cu} / \mathrm{ZnO} / \mathrm{Al}_{2} \mathrm{O}_{3}$ catalyst (MDC-7). To elucidate the sustainability of CP-823, a long-term life test of CP-823 catalyst was carried out. The change in $\mathrm{CO}$ conversion against the number of cycles of DSS operation was shown in Fig.

14. The activity was increasing up to 10 cycles, and no degradation was observed until 500 cycles of DSS operation. It is clearly shown that CP-823 is a highly active and sustainable catalyst against the DSS operations.

\section{Conclusion}

From above results, we conclude that $\mathrm{CP}-823$ can act as a highly sustainable catalyst against the DSS-like operation in the WGS reaction. CP-823 showed high activity and sustainability even after 500 cycles of DSS operation. The high and stable activity of $\mathrm{CP}-823$ is caused by the formation of highly dispersed and stable $\mathrm{Cu}$ metal. The important role of boehmite phase formed "in-situ" during the DSS operation in inhibition of aggregation of $\mathrm{Cu}$ metal particles was clearly demonstrated.

\section{Acknowledgements}


Nishimura et al. Novel catalytic behavior of $\mathrm{Cu} / \mathrm{Al}_{2} \mathrm{O}_{3}$ catalyst against daily start-up and shut-down (DSS)-like operation in the water gas shift reaction $26 / 46$

TS acknowledges the Grant-in-Aid for Scientific Research for Young Researchers (B)

(No. 19760545) under the Ministry of Education, Culture, Sports Science and Technology

(MEXT) of Japan. A part of this work is supported by the New Energy and Industrial Technology Development Organization (NEDO) in Japan. KT is supported by the Program for Improvement of Research Environment for Young Researchers from Special Coordination Funds for Promoting Science and Technology (SCF) commissioned by the Ministry of Education, Culture, Sports, Science and Technology (MEXT) of Japan.

\section{References}

[1] G. G. Scherer, Solid State Ionics 94 (1997) 249.

[2] S. Ahmed, M. Krumpelt, Int. J. Hydrogen Energy 26 (2001) 291.

[3] A. T. Ashcroft, Ak. K. Cheetham, J. S. Ford. M. L. H. Green, C. P. Grey, A. Murrell, P. D. F. Vernon, Nature 344 (1990) 259.

[4] J. R. Rostrup-Nielsen, Catal. Today 71 (2002) 243.

[5] K. Takehira, T. Shishido, Catal. Surv. Asia 11 (2007) 1.

[6] S. Liu, L. Xu, S. Xie, Q. Wang, G. Xiong, Appl. Catal. A 211 (2001) 145. 
Nishimura et al.

Novel catalytic behavior of $\mathrm{Cu} / \mathrm{Al}_{2} \mathrm{O}_{3}$ catalyst against daily start-up and shut-down (DSS)-like operation in the water gas shift reaction $27 / 46$

[7] N. M. Schmidt, P. Bröcheehoff, B. Höhlein, R. Menzer, U. Stimming, J. Power Sources 49 (1994) 299.

[8] F. Vidal, B. Busson, C. Six, O. Pluchery, A. Tadjeddine, Surf. Sci. 502-503 (2002) 485.

[11] M. J. L. Ginés, N. Amadeo, M. Laborde, C. R. Apesteguía. Appl. Catal. A 131 (1995) 283.

[12] K. Sekizawa, S.-I. Yano, K. Eguchi, H. Arai, Appl. Catal. A 169 (1998) 291.

[13] J. Wu, M. Saito, J. Catal. 195 (2000) 420.

[14] Y. Tanaka, T. Utaka, R.Kikuchi, K. Sasaki, K. Eguchi, Appl. Catal. A 242 (2003) 287.

[15] M. Rønning, F. Huber, H. Meland, H. Venvik, D. Chen, A. Holmen, Catal. Today, 100, (2005) 249.

[16] T. Shishido, M. Yamamoto, I. Atake, D. Li, Y. Tian, H. Morioka, M. Honda, T. Sano, K. Takehira, J. Mol. Catal. A 253 (2006) 270.

[17] Y. Tanaka, T. Takeguchi, R.Kikuchi, K. Eguchi, Appl. Catal. A 279 (2005) 59.

[18] T. Shishido, S. Nishimura, Y. Yoshinaga, K. Ebitani, K. Teramura, T. Tanaka, Catal. Commun., 10 (2009) 1057.

[19] Y. Li, Q. Fu, M. Flytzani-Stephanopoulos, Appl. Catal. B 27 (2000) 179.

[20] S. Hilaire, X. Wang, T. Luo, R.J. Gorte, J. Wagner, Appl. Catal A. 215 (2001) 271. 
Nishimura et al.

Novel catalytic behavior of $\mathrm{Cu} / \mathrm{Al}_{2} \mathrm{O}_{3}$ catalyst against daily start-up and shut-down (DSS)-like operation in the water gas shift reaction $28 / 46$

[21] T. Tabakova, F. Boccuzzi, M. Manzoli, D. Andreeva, Appl. Catal. A 252 (2003) 385.

[22] Q. Fu,W. Deng, H. Saltsburg, M. Flytzani-Stephanopoulos, Appl. Catal. B 56 (2005) 57.

[23] E.S. Bickford, S. Velu, C. Song, Catal. Today 99 (2005) 347.

[24] J.M. Zalc, V. Sokolovskii, D.G. Loffler, Appl. Catal. A 215 (2001) 271.

[25] P. Panagiotopoulou, D.I. Kondarides, J. Catal. 225 (2004) 327.

[26] T. Utaka, T. Takeguchi, R. Kikuchi, K. Eguchi, Appl. Catal. 246 (2003) 117.

[27] T. Utaka, T. Okanishi, T. Takeguchi, R. Kikuchi, K. Eguchi, Appl. Catal. A 245 (2003)

343.

[28] A. Venugopal, M.S. Scurrell, Appl. Catal. A 245 (2003) 137.

[29] Y. Tanaka, T. Utaka, T. Takeguchi, R.Kikuchi, K. Eguchi, Appl. Catal. A 238 (2003) 11.

[30] R.J. Candal, A.E. Regazzoni, M.A. Blesa, J. Mater. Chem. 2 (1992) 657.

[31] G.J. de A.A. Soler-Illia, R.J. Candal, A.E. Regazzoni, M.A. Blesa, Chem. Mater. 9 (1997)

184.

[32] H. Morioka, H. Tagaya, K. Karasu, J. Kadokawa, K. Chiba, J. Solid State Chem. 117

(1995) 337.

[33] T. Hayakawa, H. Harihara, A. G. Anderse, A. P. E. York, K. Suzuki, H. Yasuda, K.

Takehira, Angew. Int. Chem. Int. Ed. 35 (1996) 192. 
Nishimura et al.

Novel catalytic behavior of $\mathrm{Cu} / \mathrm{Al}_{2} \mathrm{O}_{3}$ catalyst against daily start-up and shut-down (DSS)-like operation in the water gas shift reaction $29 / 46$

[34] K. Takrhia, T. Shishido, M. Kondo, J. Catal. 207 (2002) 307.

[35] J. W. Evans, M. S. Wainwright, A. J. Bridgewater. D. J. Young., Appl. Catal., 7 (1983)

75.

[36] A. Suzuki and M. Nomura, Proceedings of 9 th Japan XAFS society Annual meeting,

7008.

[37] W. Ruettinger, O. Ilich, R. J. Farruato, J. Power Sorce 118 (2003) 61.

[38] H. Yahiro, K. Nakaya, T. Yamamoto, K. Saiki, H. Yamamura, Catal. Commun. 7 (2006) 228.

[39] F. Severino, J. L. Brito, J. Laine, J. L. G. Fierro, A.L. Agudo, J. Catal. 177 (1998) 82.

[40] M. F. Luo, P. Fang, M. He, Y. L. Xie, J. Mol. Catal. A 239 (2005) 243.

[41] T. Shishido, Y. Yamamoto, H. Morioka, K. Takaki, K. Takehira, Appl. Catal. A. 263 (2004) 249.

[42] H. Ivankovic, E. Tkalcec, R. Nass, H. Schmidt, J. Eur. Ceram. Soc. 23 (2003) 283.

[43] J. Agrell, H. Brigersson, M. Boutonnet, I. Melian-Cabrera, R. M. Navarro, J. L. G. Fierro, J. Catal. 219 (2003) 389. 
Nishimura et al.

Novel catalytic behavior of $\mathrm{Cu} / \mathrm{Al}_{2} \mathrm{O}_{3}$ catalyst against daily start-up and shut-down (DSS)-like operation in the water gas shift reaction $30 / 46$

Figure captions

Fig. 1. Diagram of DSS-like operation in the WGS reaction.

Fig. 2. Diagram of in-situ time-resolved XANES experiment.

Fig. 3. XRD patterns of $\mathrm{Cu} / \mathrm{Al}_{2} \mathrm{O}_{3}$ catalysts calcined at various temperatures. (A) $\mathrm{CP}-$ and (B) IMP-, (a) before calcination, (b) calcined at $573 \mathrm{~K}$, (c) $873 \mathrm{~K}$, (d) $973 \mathrm{~K}$, (e) $1023 \mathrm{~K}$, (f) 1073 $\mathrm{K},(\mathrm{g}) 1173 \mathrm{~K},(*)$ hydrotalcite-like compound, ( $\mathbf{\square}) \mathrm{CuO},(\bigcirc) \mathrm{CuAl}_{2} \mathrm{O}_{4}$.

Fig. 4. $\mathrm{TPR}$ profiles of $\mathrm{Cu} / \mathrm{Al}_{2} \mathrm{O}_{3}$ catalysts calcined at various temperatures. (A) $\mathrm{CP}-$ and (B) IMP-, (a) $823 \mathrm{~K}$, (b) $873 \mathrm{~K}$, (c) $973 \mathrm{~K}$, (d) $1023 \mathrm{~K}$, (e) $1073 \mathrm{~K}$, (f) $1173 \mathrm{~K}$. The numbers by peaks are the amount of $\mathrm{H}_{2}$ consumed.

Fig. 5. Catalytic activity and $\mathrm{Cu}^{0}$ surface area of $\mathrm{Cu} / \mathrm{Al}_{2} \mathrm{O}_{3}$ catalysts as a function of calcination temperature. (A) $\mathrm{CP}-$ and (B) $\mathrm{IMP}-\mathrm{Cu} / \mathrm{Al}_{2} \mathrm{O}_{3}$. Reaction temperature $473 \mathrm{~K}$, $\mathrm{CO} / \mathrm{CO}_{2} / \mathrm{H}_{2} \mathrm{O} / \mathrm{H}_{2}=7.3 / 7.3 / 27.2 / 58.3, \mathrm{GHSV}=12.4 \mathrm{~L} \mathrm{~h}^{-1} \mathrm{~g}-\mathrm{cat}^{-1}$.

Fig. 6. Time course of $\mathrm{CO}$ conversion over $\mathrm{Cu} / \mathrm{Al}_{2} \mathrm{O}_{3}$ catalysts, (A) before DSS-like operation and (B) after 10 cycles of DSS-like operation, ( $\mathbf{O})$ CP-823, (○) CP-1073, ( $\mathbf{\Delta}$ ) IMP-823, $(\triangle)$ IMP-1073, (*) commercial $\mathrm{Cu} / \mathrm{ZnO} / \mathrm{Al}_{2} \mathrm{O}_{3}$ catalyst (MDC-7), Reaction temperature 473 $\mathrm{K}, \mathrm{CO} / \mathrm{CO}_{2} / \mathrm{H}_{2} \mathrm{O} / \mathrm{H}_{2}=7.3 / 7.3 / 27.2 / 58.3, \mathrm{GHSV}=12.4 \mathrm{~L} \mathrm{~h}^{-1} \mathrm{~g}^{-\mathrm{cat}^{-1}}$. 
Nishimura et al. Novel catalytic behavior of $\mathrm{Cu} / \mathrm{Al}_{2} \mathrm{O}_{3}$ catalyst against daily start-up and shut-down (DSS)-like operation in the water gas shift reaction $31 / 46$

Fig. 7. The change in catalytic activity in the water-gas shift reaction by the DSS-like operation over $\mathrm{Cu} / \mathrm{Al}_{2} \mathrm{O}_{3}$, and commercial $\mathrm{Cu} / \mathrm{ZnO} / \mathrm{Al}_{2} \mathrm{O}_{3}$ (MDC-7) catalysts. Reaction temperature $473 \mathrm{~K}, \mathrm{CO} / \mathrm{CO}_{2} / \mathrm{H}_{2} \mathrm{O} / \mathrm{H}_{2}=7.3 / 7.3 / 27.2 / 58.3, \mathrm{GHSV}=12.4 \mathrm{~L} \mathrm{~h}^{-1}$ g-cat ${ }^{-1}$.

Fig. 8. XRD patterns of $\mathrm{Cu} / \mathrm{Al}_{2} \mathrm{O}_{3}$ catalysts after 10 cycles of DSS-like operation, (A) calcined at $823 \mathrm{~K}$, (B) calcined at $1073 \mathrm{~K}$, (a) CP-, (b) HP- (c) SG- and (d) IMP-Cu/ $\mathrm{Al}_{2} \mathrm{O}_{3}$ catalysts. ( $\square) \mathrm{Cu}$ metal, ( $) \mathrm{AlO}(\mathrm{OH}),(\bigcirc) \mathrm{CuAl}_{2} \mathrm{O}_{4},(\nabla) \gamma-\mathrm{Al}_{2} \mathrm{O}_{3}$.

Fig. 9. XRD patterns of (A) $\mathrm{CP}-$ and (B) IMP-Cu/ $/ \mathrm{Al}_{2} \mathrm{O}_{3}$ catalysts, (a) calcined at $823 \mathrm{~K}$, (b) reduced at $523 \mathrm{~K}$, (c) after $1^{\text {st }}$ DSS-like operation, (d) after 10 cycles of DSS, (e) after 20 cycles of DSS, and (f) after 50 cycles of DSS. ( $\mathbf{\square}) \mathrm{CuO},(\square) \mathrm{Cu}$ metal, ( $\boldsymbol{\nabla}) \mathrm{AlO}(\mathrm{OH}),(\nabla)$ $\gamma-\mathrm{Al}_{2} \mathrm{O}_{3}$

Fig. 10. TEM images of CP-823 and IMP-823 catalysts before and after DSS-like operation. (a) and (b), CP-823; (c) and (d), IMP-823.

Fig. 11. TPR profiles of CP-823 and IMP-823 catalysts before and after the DSS-like operation. (A) CP-823, (B) IMP-823. The numbers by peaks are the amount of $\mathrm{H}_{2}$ consumed. (a) calcined at $823 \mathrm{~K}$, (b) reduced at $523 \mathrm{~K}$, (c) after 10 cycles of DSS, (d) after 20 cycles of DSS. The thin lines are TPR profiles of CP- and IMP-823, which were applied to 10 cycles of DSS-like operation, then were oxidized at $573 \mathrm{~K}$. 
Nishimura et al.

Novel catalytic behavior of $\mathrm{Cu} / \mathrm{Al}_{2} \mathrm{O}_{3}$ catalyst against daily start-up and shut-down (DSS)-like operation in the water gas shift reaction $32 / 46$

Fig. 12. $\mathrm{Cu}$ K-edge XANES spectra of (A) CP-823 and (B) IMP-823 catalysts during the DSS-like operation. The diagram is shown in Fig. 2. The dashed line was under the WGS reaction condition, and the solid line was under the DSS-like operation.

Fig. 13. Evolution of $\mathrm{Cu}$ composition over the (A) CP-823 and (B) IMP-823 catalysts during DSS-like operation, $(\diamond) \mathrm{Cu}^{0},(\bigcirc) \mathrm{Cu}^{+}$, and $(\triangle) \mathrm{Cu}^{2+}$. The diagram is shown in Fig. 2.

Fig. 14. The change in catalytic activity of CP-823 catalyst against the DSS operations. Reaction condition; catalyst $10 \mathrm{cc}, \mathrm{CO} / \mathrm{CO}_{2} / \mathrm{H}_{2} \mathrm{O} / \mathrm{H}_{2}$ (9.5/6.8/27.5/56.2), GHSV=700 h ${ }^{-1}$, Reaction temperature $473 \mathrm{~K}$. 
Nishimura et al.

Novel catalytic behavior of $\mathrm{Cu} / \mathrm{Al}_{2} \mathrm{O}_{3}$ catalyst against daily start-up and shut-down (DSS)-like operation in the water gas shift reaction $33 / 46$

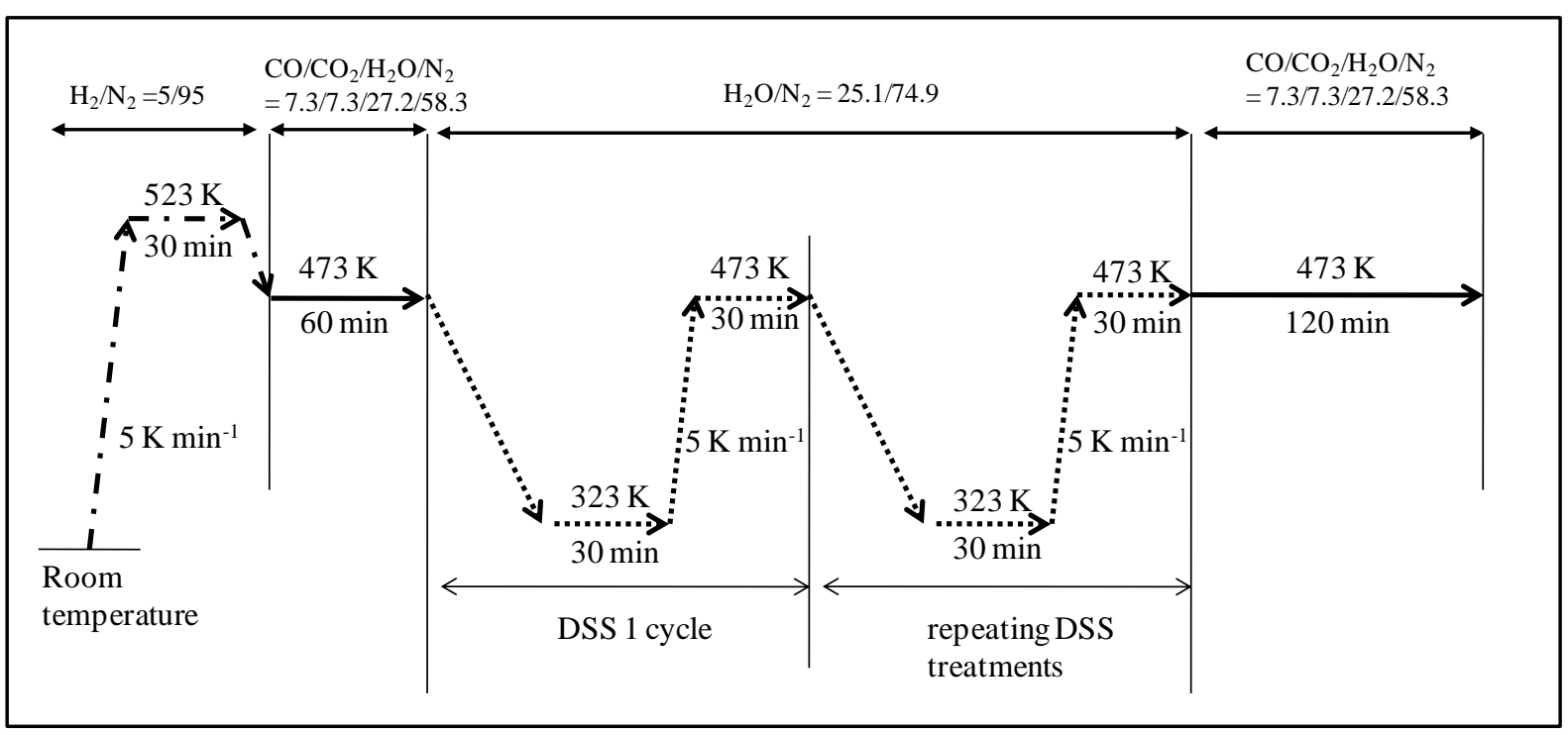

Fig. 1. Diagram of DSS-like operation in the WGS reaction. 
Nishimura et al.

Novel catalytic behavior of $\mathrm{Cu} / \mathrm{Al}_{2} \mathrm{O}_{3}$ catalyst against daily start-up and shut-down (DSS)-like operation in the water gas shift reaction $34 / 46$

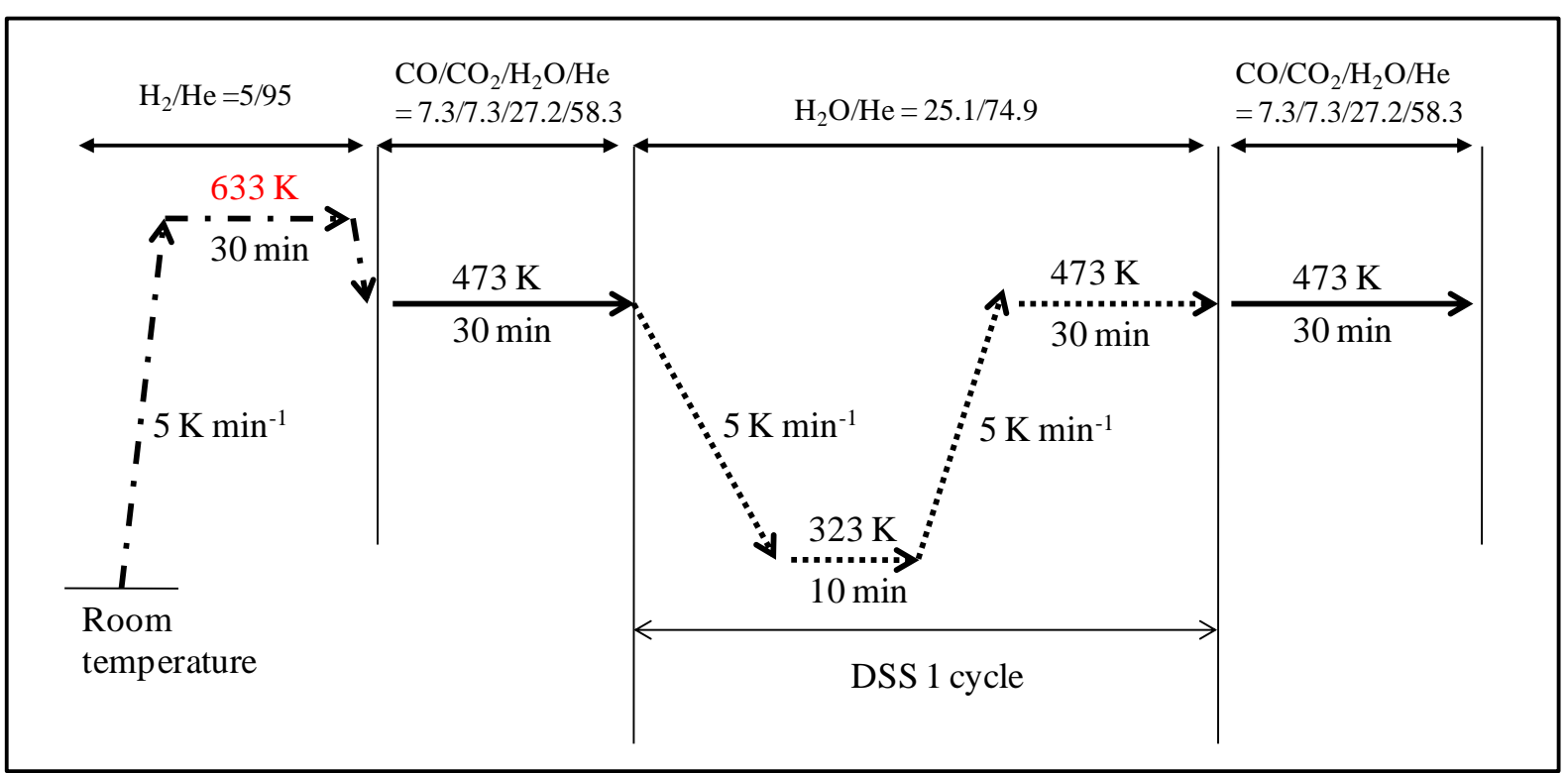

Fig. 2. Diagram of in-situ time-resolved XANES experiment. 
Nishimura et al.

Novel catalytic behavior of $\mathrm{Cu} / \mathrm{Al}_{2} \mathrm{O}_{3}$ catalyst against daily start-up and shut-down (DSS)-like operation in the water gas shift reaction $35 / 46$
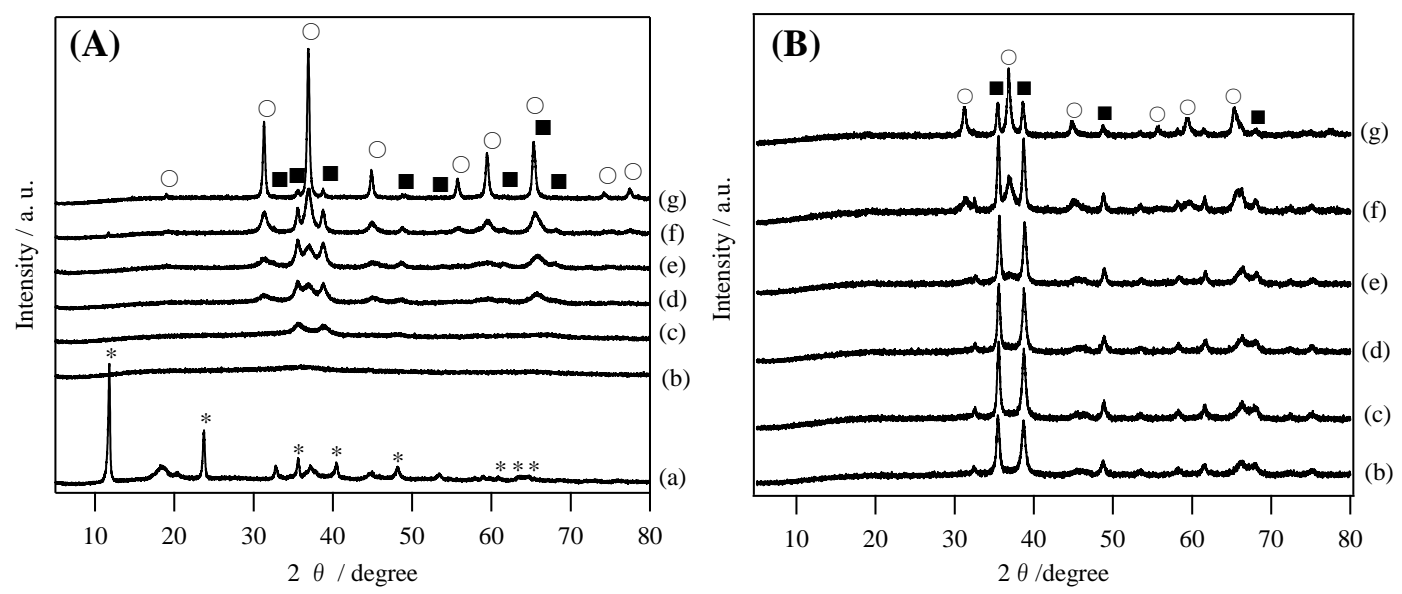

Fig. 3. XRD patterns of $\mathrm{Cu} / \mathrm{Al}_{2} \mathrm{O}_{3}$ catalysts calcined at various temperatures. (A) $\mathrm{CP}-$ and (B) IMP-, (a) before calcination, (b) calcined at $573 \mathrm{~K}$, (c) $873 \mathrm{~K}$, (d) $973 \mathrm{~K}$, (e) $1023 \mathrm{~K}$, (f) 1073 $\mathrm{K},(\mathrm{g}) 1173 \mathrm{~K},(*)$ hydrotalcite-like compound, ( $\boldsymbol{\square}) \mathrm{CuO},(\bigcirc) \mathrm{CuAl}_{2} \mathrm{O}_{4}$. 
Nishimura et al.

Novel catalytic behavior of $\mathrm{Cu} / \mathrm{Al}_{2} \mathrm{O}_{3}$ catalyst against daily start-up and shut-down (DSS)-like operation in the water gas shift reaction $36 / 46$
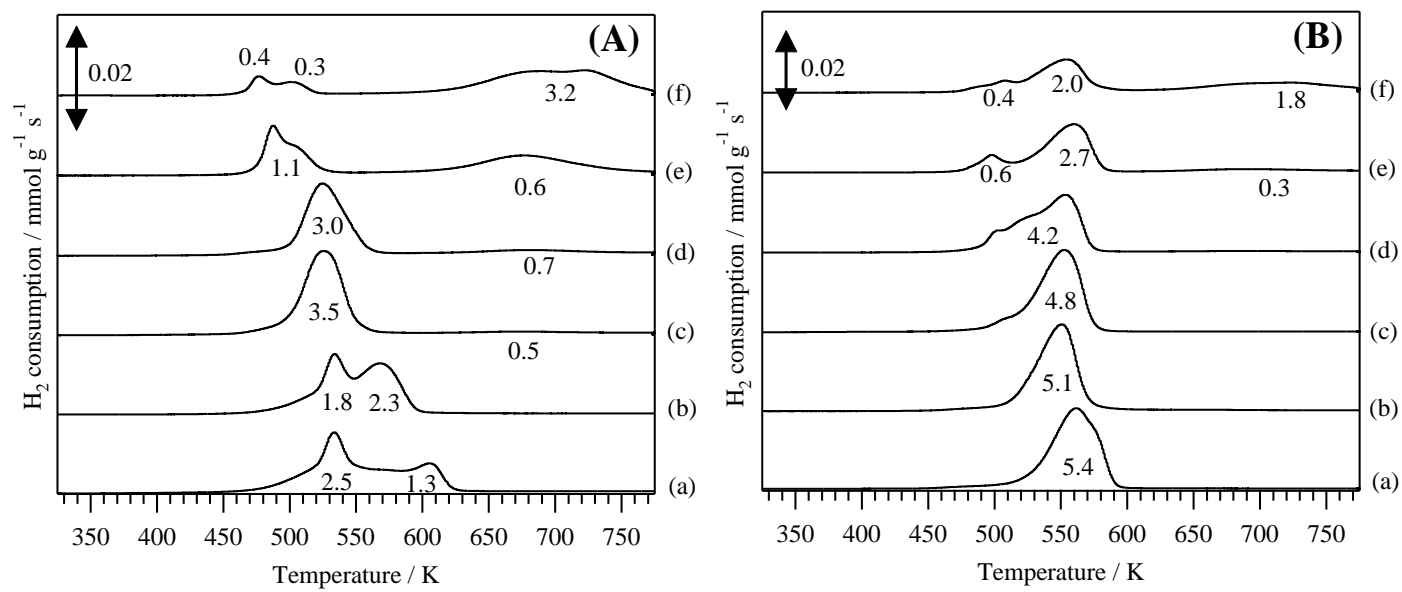

Fig. 4. TPR profiles of $\mathrm{Cu} / \mathrm{Al}_{2} \mathrm{O}_{3}$ catalysts calcined at various temperatures. (A) $\mathrm{CP}-$ and (B) IMP-, (a) $823 \mathrm{~K}$, (b) $873 \mathrm{~K}$, (c) $973 \mathrm{~K}$, (d) $1023 \mathrm{~K}$, (e) $1073 \mathrm{~K}$, (f) $1173 \mathrm{~K}$. The numbers by peaks are the amount of $\mathrm{H}_{2}$ consumed. 
Nishimura et al.

Novel catalytic behavior of $\mathrm{Cu} / \mathrm{Al}_{2} \mathrm{O}_{3}$ catalyst against daily start-up and shut-down (DSS)-like operation in the water gas shift reaction $37 / 46$
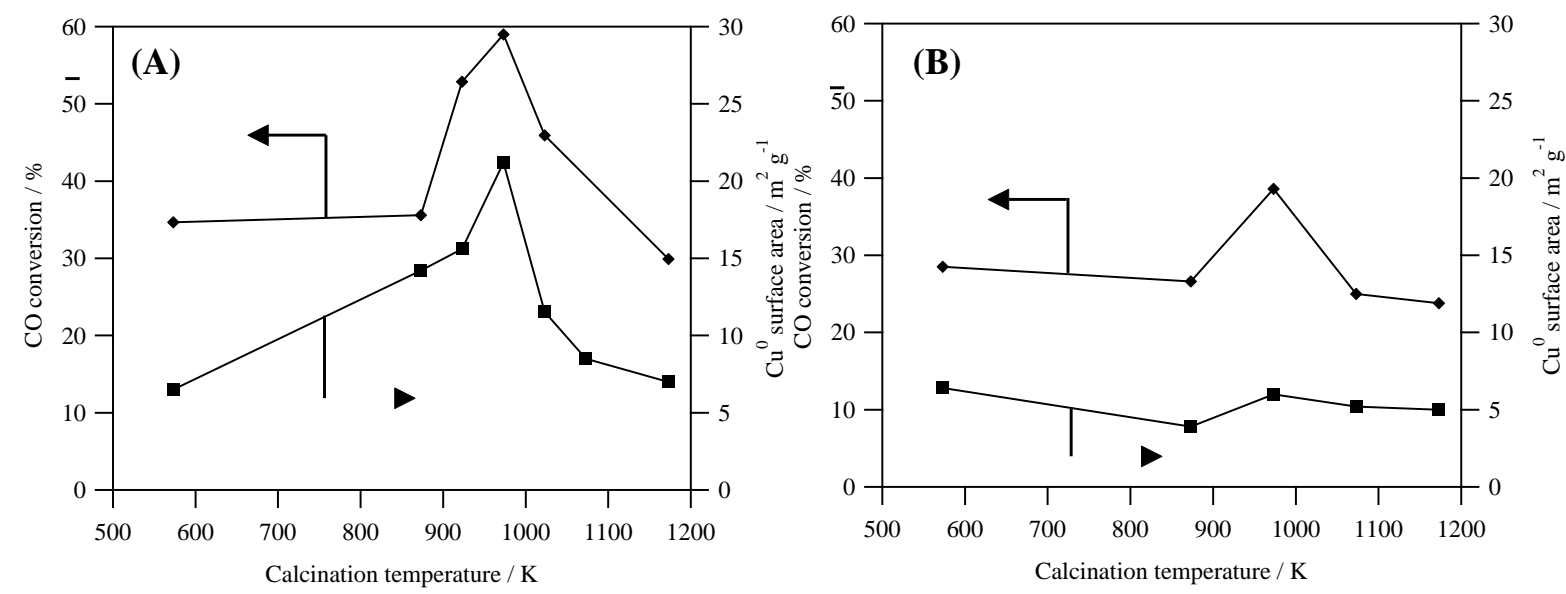

Fig. 5. Catalytic activity and $\mathrm{Cu}^{0}$ surface area of $\mathrm{Cu} / \mathrm{Al}_{2} \mathrm{O}_{3}$ catalysts as a function of calcination temperature. (A) $\mathrm{CP}-$ and (B) $\mathrm{IMP}-\mathrm{Cu} / \mathrm{Al}_{2} \mathrm{O}_{3}$. Reaction temperature $473 \mathrm{~K}$, $\mathrm{CO} / \mathrm{CO}_{2} / \mathrm{H}_{2} \mathrm{O} / \mathrm{H}_{2}=7.3 / 7.3 / 27.2 / 58.3, \mathrm{GHSV}=12.4 \mathrm{~L} \mathrm{~h}^{-1} \mathrm{~g}^{-\mathrm{cat}^{-1}}$. 
Nishimura et al.

Novel catalytic behavior of $\mathrm{Cu} / \mathrm{Al}_{2} \mathrm{O}_{3}$ catalyst against daily start-up and shut-down (DSS)-like operation in the water gas shift reaction
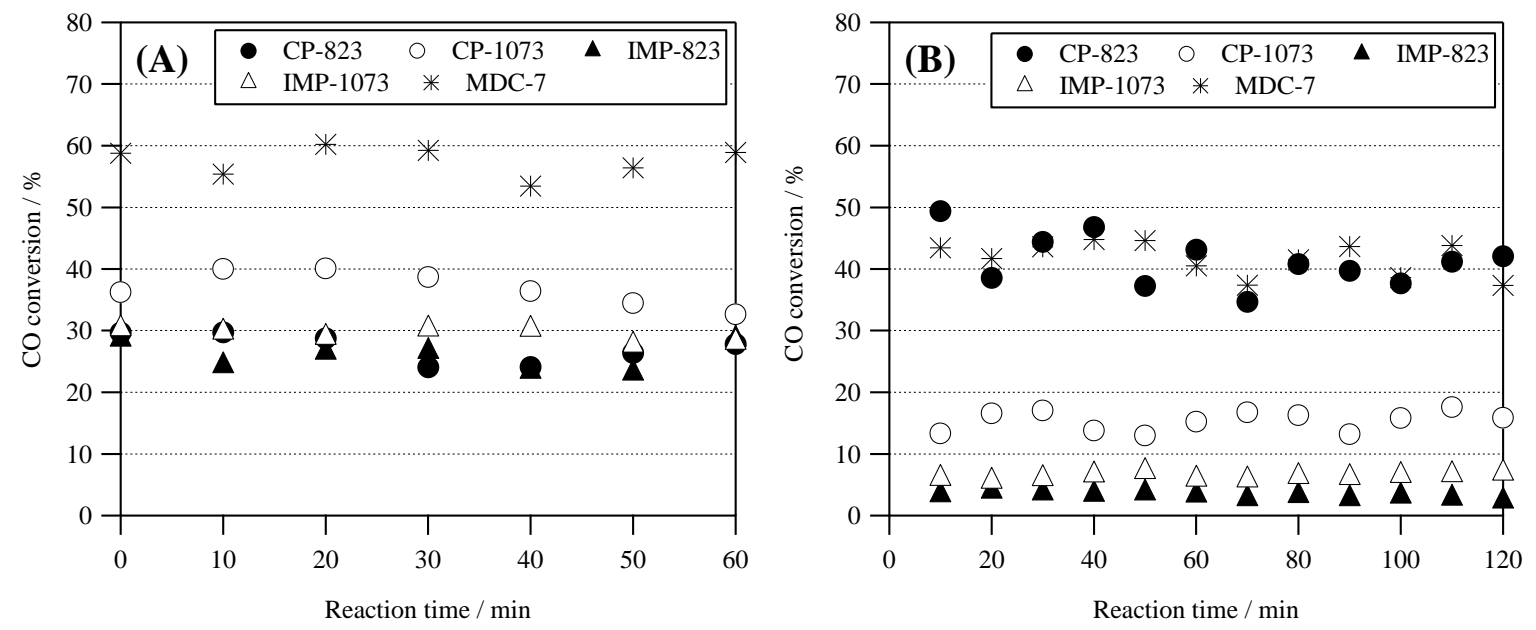

Fig. 6. Time course of $\mathrm{CO}$ conversion over $\mathrm{Cu} / \mathrm{Al}_{2} \mathrm{O}_{3}$ catalysts, (A) before DSS-like operation and (B) after 10 cycles of DSS-like operation, ( $\mathbf{O})$ CP-823, (○) CP-1073, ( $\mathbf{\Delta}$ ) IMP-823, $\left(\triangle\right.$ ) IMP-1073, (*) commercial $\mathrm{Cu} / \mathrm{ZnO} / \mathrm{Al}_{2} \mathrm{O}_{3}$ catalyst (MDC-7), Reaction temperature 473 $\mathrm{K}, \mathrm{CO} / \mathrm{CO}_{2} / \mathrm{H}_{2} \mathrm{O} / \mathrm{H}_{2}=7.3 / 7.3 / 27.2 / 58.3, \mathrm{GHSV}=12.4 \mathrm{~L} \mathrm{~h}^{-1} \mathrm{~g}-\mathrm{cat}^{-1}$. 
Nishimura et al.

Novel catalytic behavior of $\mathrm{Cu} / \mathrm{Al}_{2} \mathrm{O}_{3}$ catalyst against daily start-up and shut-down (DSS)-like operation in the water gas shift reaction $39 / 46$

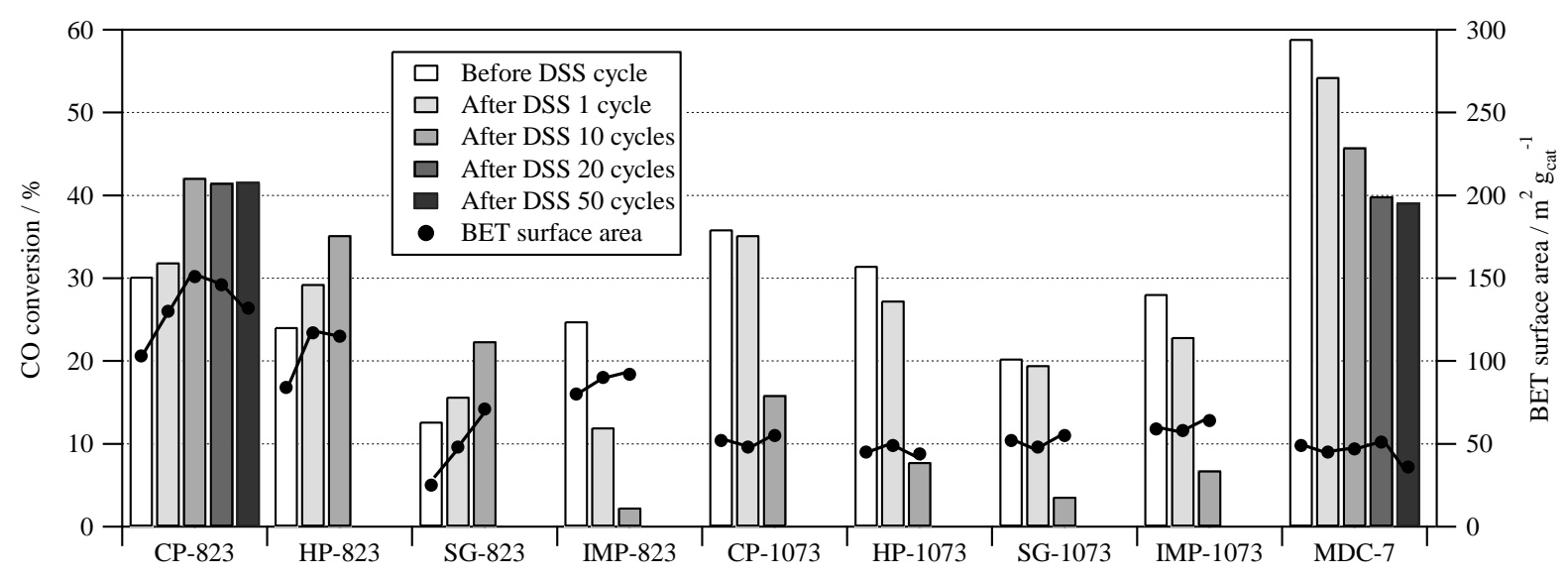

Fig. 7. The change in catalytic activity in the water-gas shift reaction by the DSS-like operation over $\mathrm{Cu} / \mathrm{Al}_{2} \mathrm{O}_{3}$, and commercial $\mathrm{Cu} / \mathrm{ZnO} / \mathrm{Al}_{2} \mathrm{O}_{3}$ (MDC-7) catalysts. Reaction temperature $473 \mathrm{~K}, \mathrm{CO} / \mathrm{CO}_{2} / \mathrm{H}_{2} \mathrm{O} / \mathrm{H}_{2}=7.3 / 7.3 / 27.2 / 58.3, \mathrm{GHSV}=12.4 \mathrm{~L} \mathrm{~h}^{-1} \mathrm{~g}^{-\mathrm{cat}^{-1}}$. 
Nishimura et al.

Novel catalytic behavior of $\mathrm{Cu} / \mathrm{Al}_{2} \mathrm{O}_{3}$ catalyst against daily start-up and shut-down (DSS)-like operation in the water gas shift reaction $40 / 46$
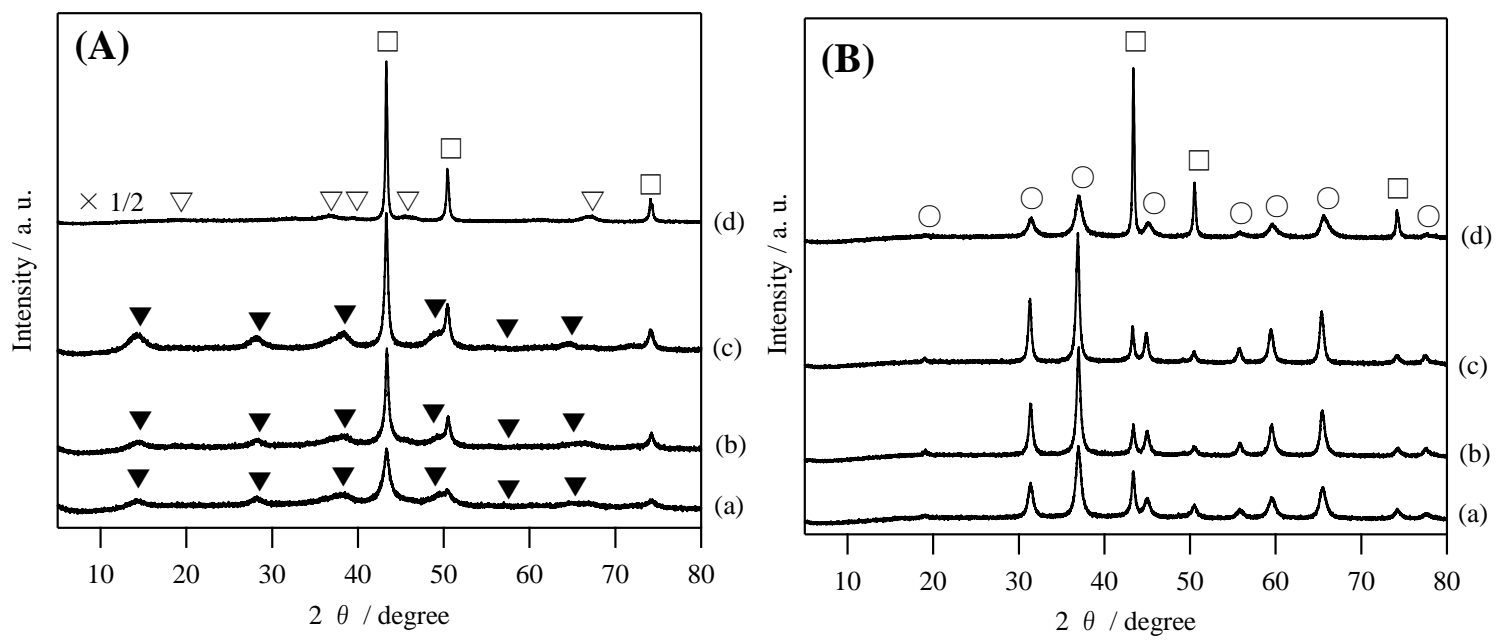

Fig. 8. XRD patterns of $\mathrm{Cu} / \mathrm{Al}_{2} \mathrm{O}_{3}$ catalysts after 10 cycles of DSS-like operation, (A) calcined at $823 \mathrm{~K}$, (B) calcined at $1073 \mathrm{~K}$, (a) CP-, (b) HP- (c) SG- and (d) IMP-Cu/ $\mathrm{Al}_{2} \mathrm{O}_{3}$ catalysts. ( $\square) \mathrm{Cu}$ metal, ( $) \mathrm{AlO}(\mathrm{OH}),(\bigcirc) \mathrm{CuAl}_{2} \mathrm{O}_{4},(\nabla) \gamma-\mathrm{Al}_{2} \mathrm{O}_{3}$. 
Nishimura et al.

Novel catalytic behavior of $\mathrm{Cu} / \mathrm{Al}_{2} \mathrm{O}_{3}$ catalyst against daily start-up and shut-down (DSS)-like operation in the water gas shift reaction
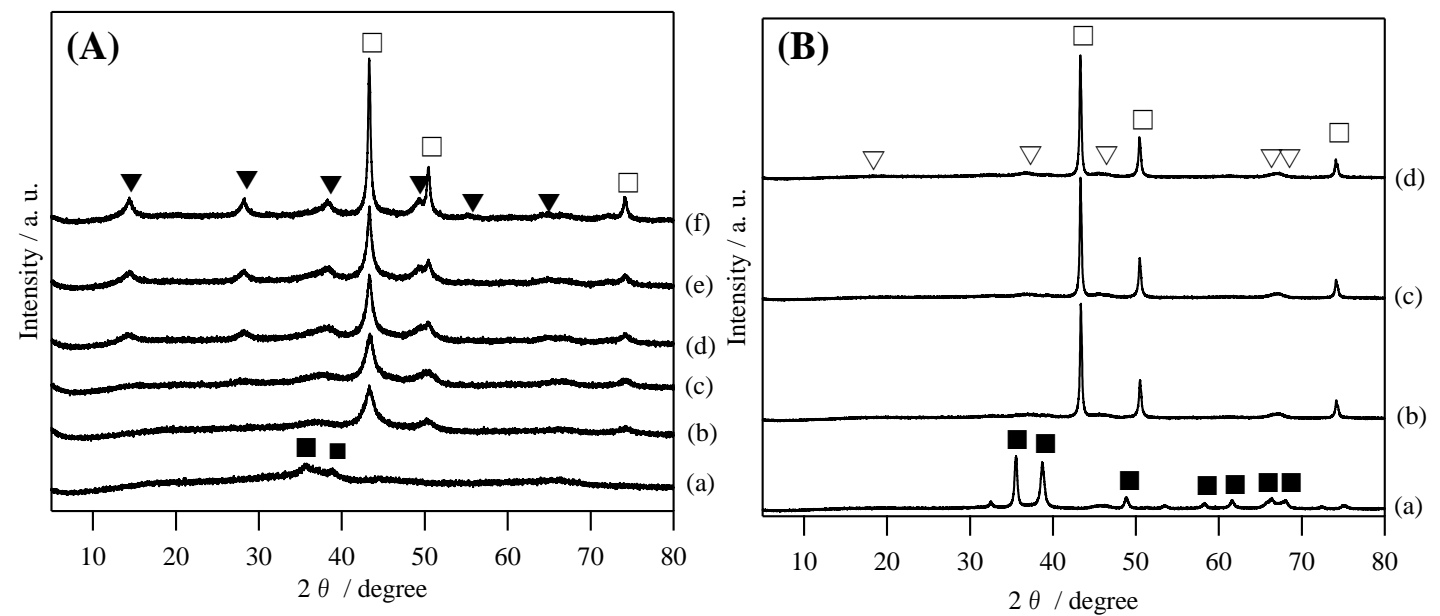

Fig. 9. XRD patterns of (A) $\mathrm{CP}$ - and (B) IMP-Cu/ $\mathrm{Al}_{2} \mathrm{O}_{3}$ catalysts, (a) calcined at $823 \mathrm{~K}$, (b) reduced at $523 \mathrm{~K}$, (c) after $1^{\text {st }}$ DSS-like operation, (d) after 10 cycles of DSS, (e) after 20 cycles of DSS, and (f) after 50 cycles of DSS. ( $\mathbf{\square}) \mathrm{CuO},(\square) \mathrm{Cu}$ metal, ( $\mathbf{\nabla}) \mathrm{AlO}(\mathrm{OH}),(\nabla)$ $\gamma-\mathrm{Al}_{2} \mathrm{O}_{3}$ 
Nishimura et al.

Novel catalytic behavior of $\mathrm{Cu} / \mathrm{Al}_{2} \mathrm{O}_{3}$ catalyst against daily start-up and shut-down (DSS)-like operation in the water gas shift reaction

$42 / 46$
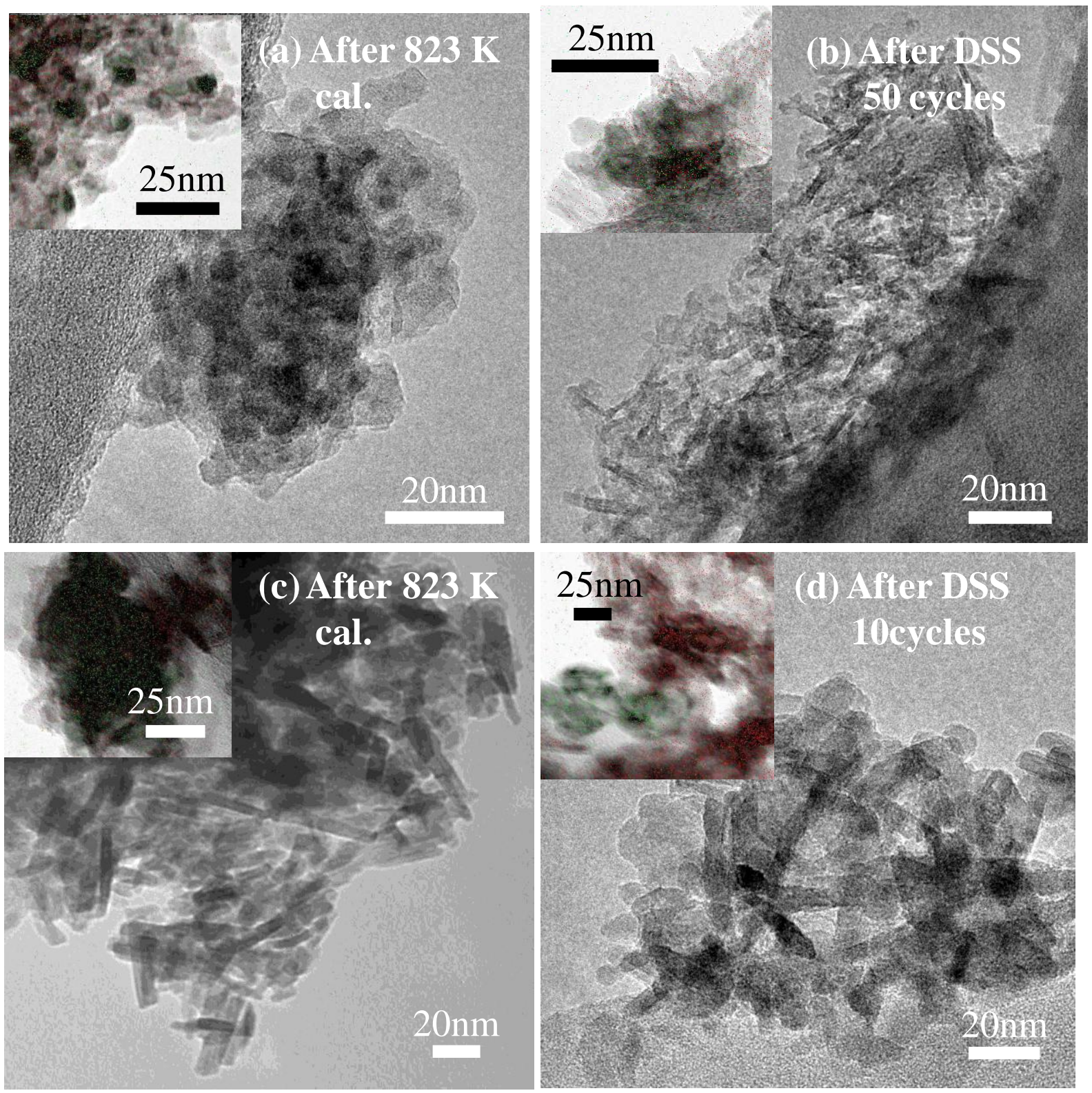

Fig. 10. TEM images of CP-823 and IMP-823 catalysts before and after DSS-like operation.

(a) and (b), CP-823; (c) and (d), IMP-823. 
Nishimura et al. Novel catalytic behavior of $\mathrm{Cu} / \mathrm{Al}_{2} \mathrm{O}_{3}$ catalyst against daily start-up and shut-down (DSS)-like operation in the water gas shift reaction
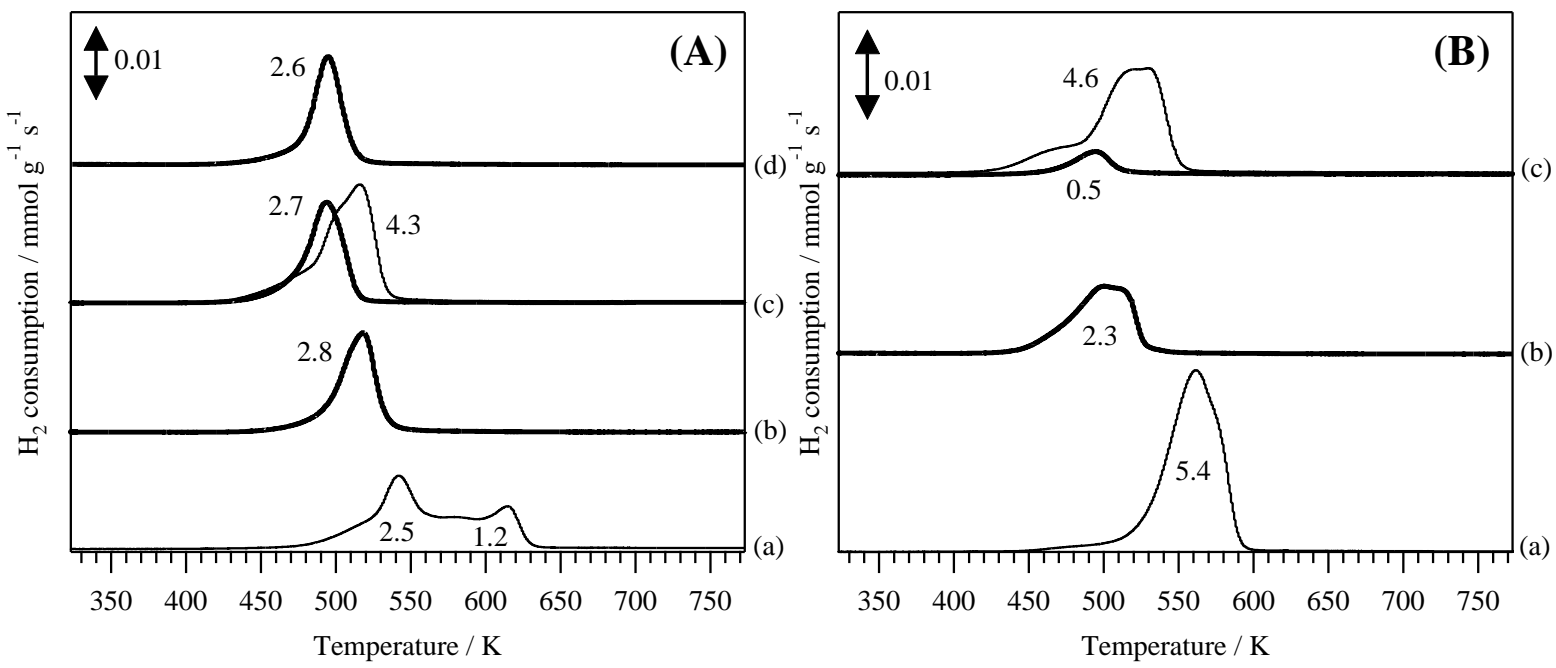

Fig. 11. TPR profiles of CP-823 and IMP-823 catalysts before and after the DSS-like operation. (A) CP-823, (B) IMP-823. The numbers by peaks are the amount of $\mathrm{H}_{2}$ consumed. (a) calcined at $823 \mathrm{~K}$, (b) reduced at $523 \mathrm{~K}$, (c) after 10 cycles of DSS, (d) after 20 cycles of DSS, The thin lines are TPR profiles of CP- and IMP-823, which were applied to 10 cycles of DSS-like operation, then were oxidized at $573 \mathrm{~K}$. 
Nishimura et al. Novel catalytic behavior of $\mathrm{Cu} / \mathrm{Al}_{2} \mathrm{O}_{3}$ catalyst against daily start-up and shut-down (DSS)-like operation in the water gas shift reaction $44 / 46$
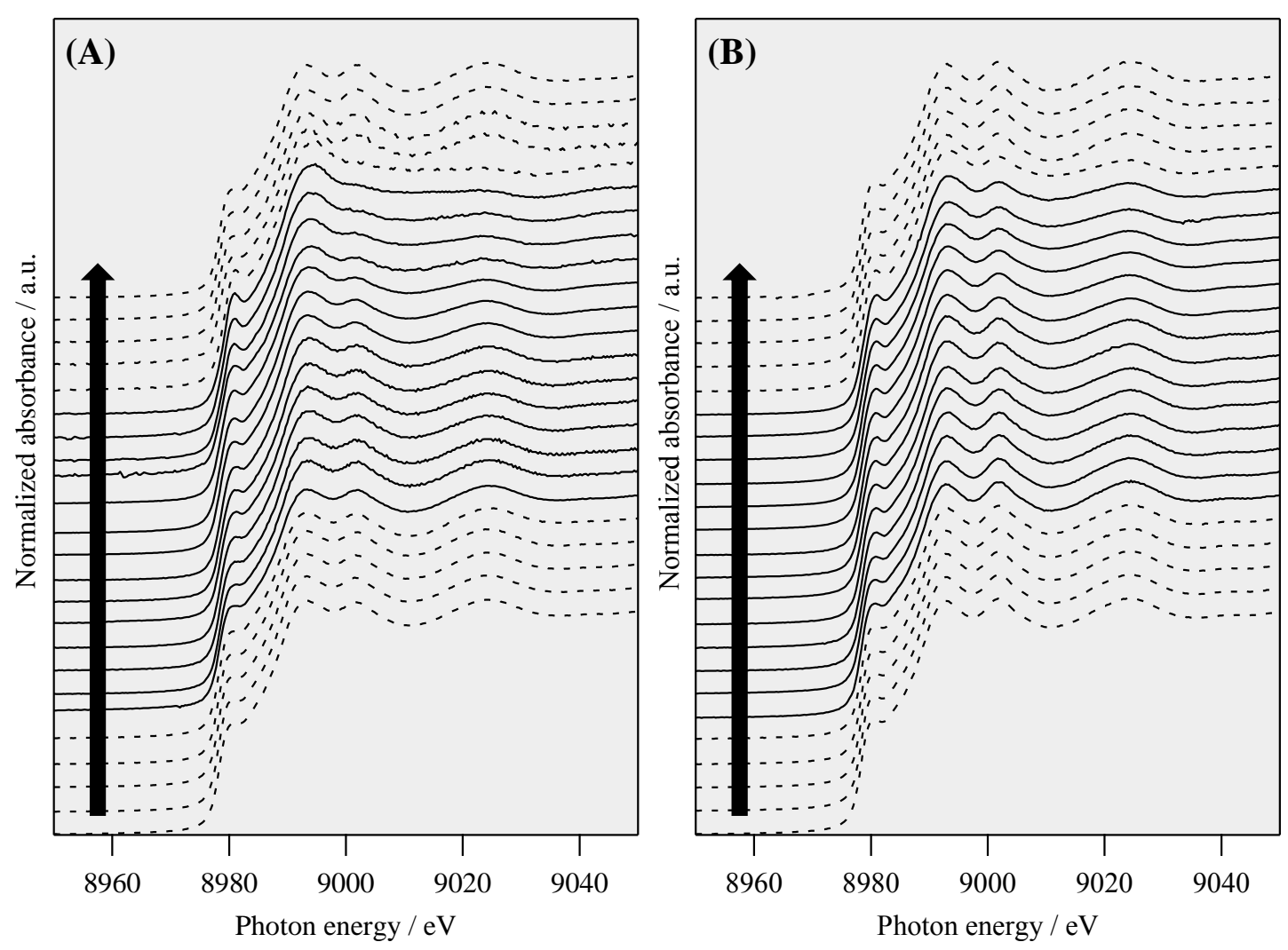

Fig. 12. $\mathrm{Cu}$ K-edge XANES spectra of (A) CP-823 and (B) IMP-823 catalysts during the DSS-like operation. The diagram is shown in Fig. 2. The dashed line was under tha WGS reaction condition, and the solid line was under the DSS-like operation. 
Nishimura et al.

Novel catalytic behavior of $\mathrm{Cu} / \mathrm{Al}_{2} \mathrm{O}_{3}$ catalyst against daily start-up and shut-down (DSS)-like operation in the water gas shift reaction
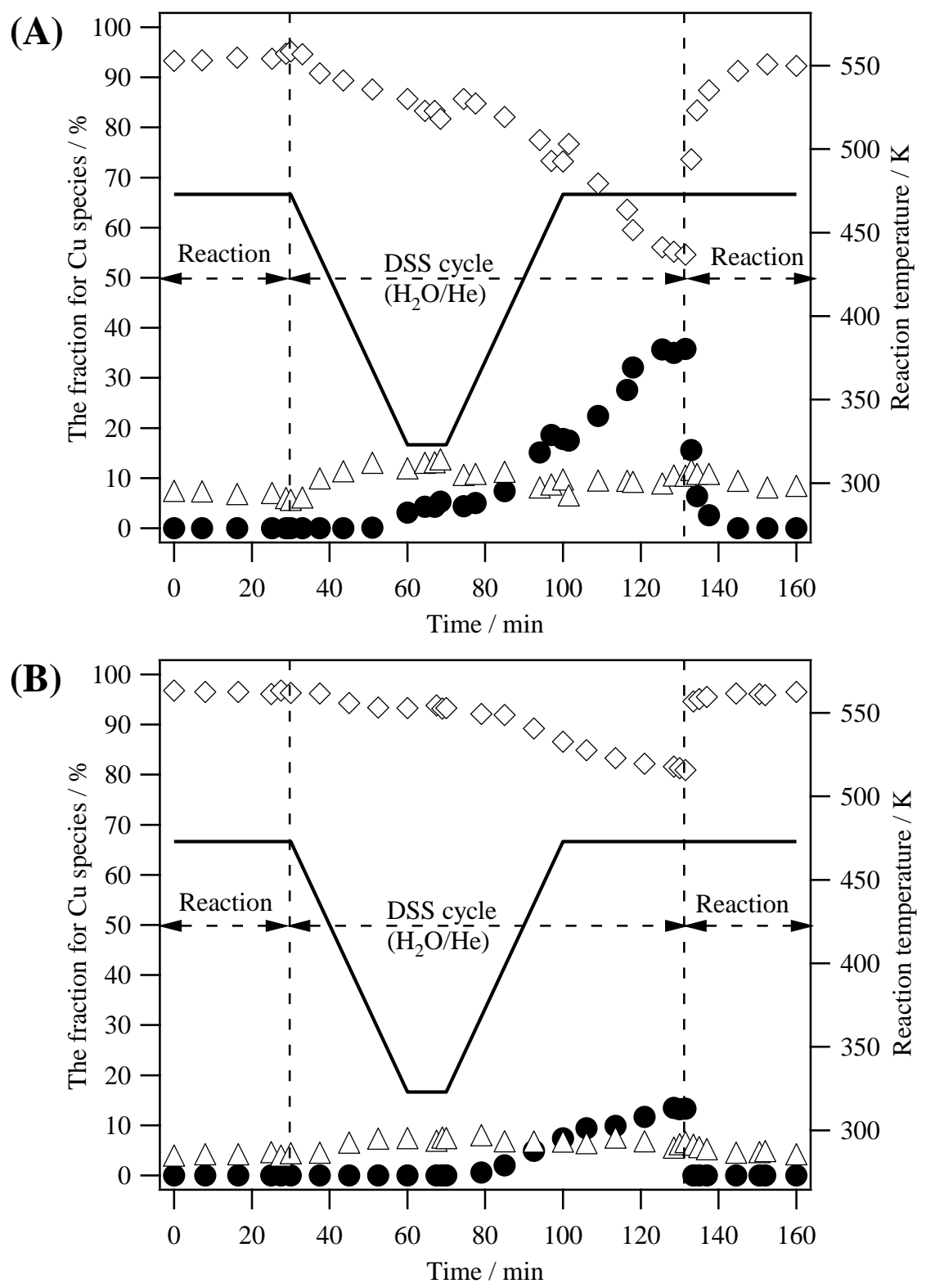

Fig. 13. Evolution of $\mathrm{Cu}$ composition over the (A) CP-823 and (B) IMP-823 catalysts during DSS-like operation, $(\diamond) \mathrm{Cu}^{0},(\bigcirc) \mathrm{Cu}^{+}$, and $(\triangle) \mathrm{Cu}^{2+}$. The diagram is shown in Fig. 2. 
Nishimura et al.

Novel catalytic behavior of $\mathrm{Cu} / \mathrm{Al}_{2} \mathrm{O}_{3}$ catalyst against daily start-up and shut-down (DSS)-like operation in the water gas shift reaction $46 / 46$

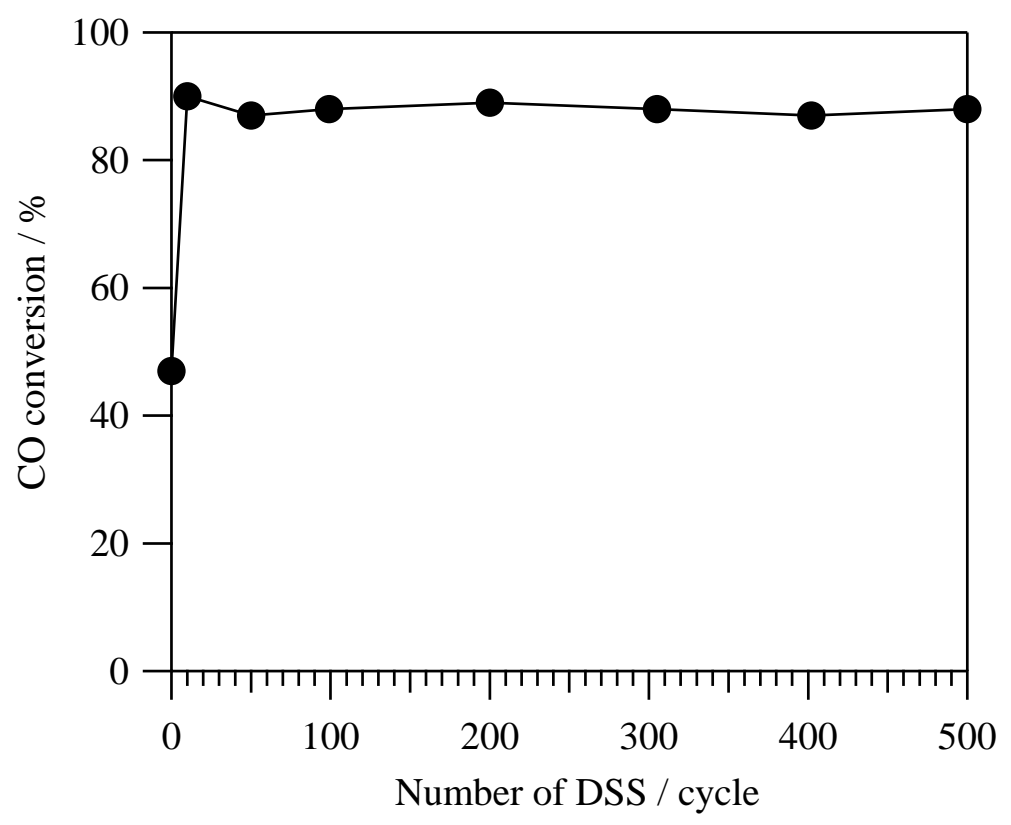

Fig. 14. The change in catalytic activity of CP-823 catalyst against the DSS operations.

Reaction condition; catalyst $10 \mathrm{cc}, \mathrm{CO} / \mathrm{CO}_{2} / \mathrm{H}_{2} \mathrm{O} / \mathrm{H}_{2}$ (9.5/6.8/27.5/56.2), GHSV=700 h-1, Reaction temperature $473 \mathrm{~K}$. 
Supporting Information for

\title{
Novel catalytic behavior of $\mathrm{Cu} / \mathrm{Al}_{2} \mathrm{O}_{3}$ catalyst against daily start-up
}

\section{and shut-down (DSS)-like operation in the water gas shift reaction}

\author{
Shun Nishimura, ${ }^{b}$ Tetsuya Shishido, ${ }^{* a}$ Kohki Ebitani, ${ }^{b}$ Kentaro Teramura, ${ }^{c}$ \\ and Tsunehiro Tanaka ${ }^{a}$
}

${ }^{a}$ Department of Molecular Engineering, Graduate School of Engineering, Kyoto University, Katsura, Kyoto 615-8510, Japan.

${ }^{b}$ School of Materials Science, Japan Advanced Institute of Science and Technology, Nomi, Ishikawa 923-1292, Japan.

${ }^{c}$ Kyoto University Pioneering Research Unit for Next Generation, Kyoto University, Katsura, Kyoto 615-8510, Japan.

\section{Corresponding author}

Dr. Tetsuya Shishido

Department of Molecular Engineering, Graduate School of Engineering, Kyoto University,

Katsura, Kyoto 615-8510, Japan.

Tel: +81 753832559

Fax: +81753832561

E-mail: shishido@moleng.kyoto-u.ac.jp 

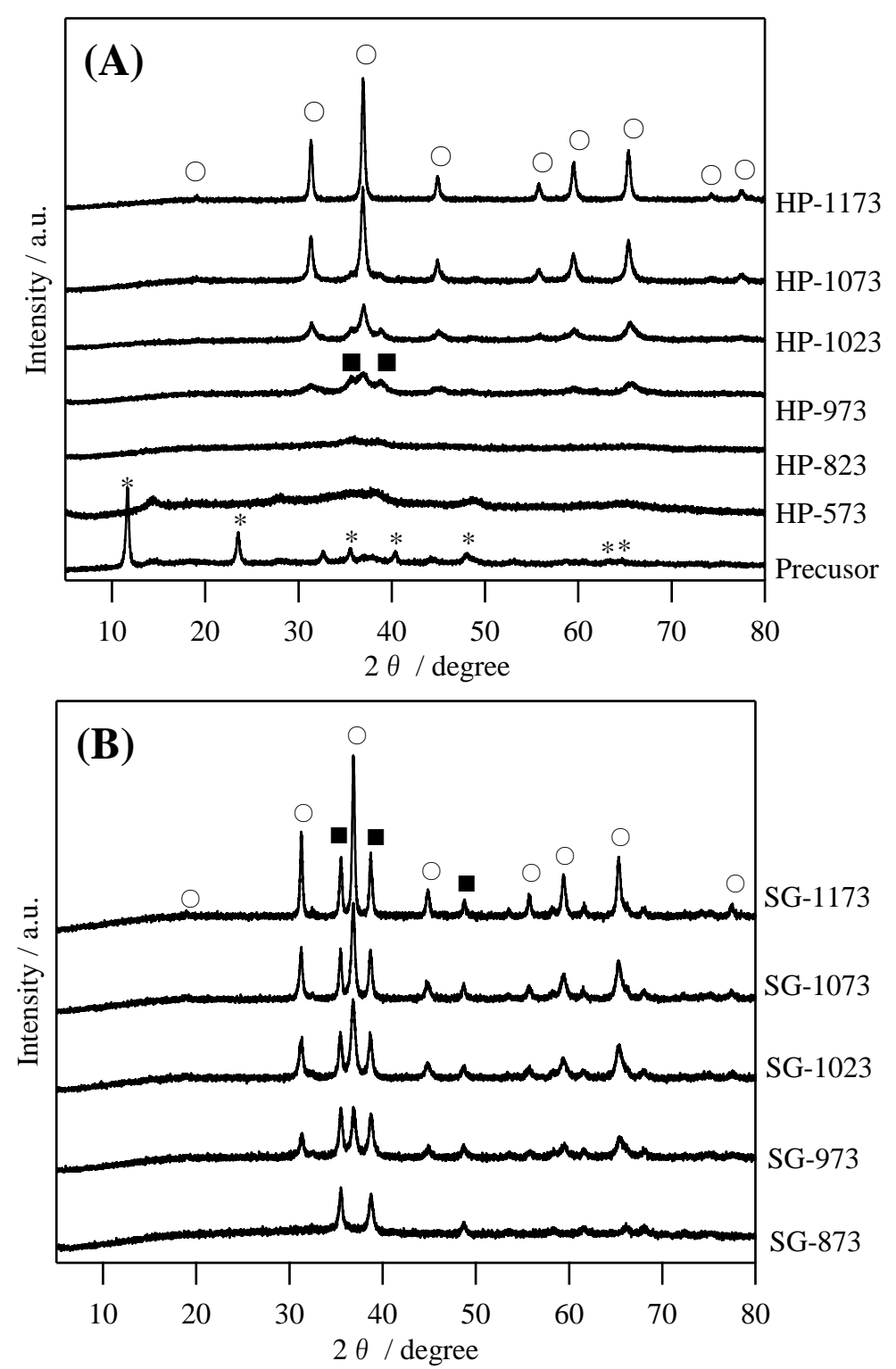

Fig. S1. XRD patterns of $\mathrm{Cu} / \mathrm{Al}_{2} \mathrm{O}_{3}$ catalysts calcined at various temperatures. (A) $\mathrm{HP}$ - and (B) $\mathrm{SG}-\mathrm{Cu} / \mathrm{Al}_{2} \mathrm{O}_{3}$, ( * ) hydrotalcite-like compund, ( $\square$ ) $\mathrm{CuO},(\bigcirc)$ $\mathrm{CuAl}_{2} \mathrm{O}_{4}$. 

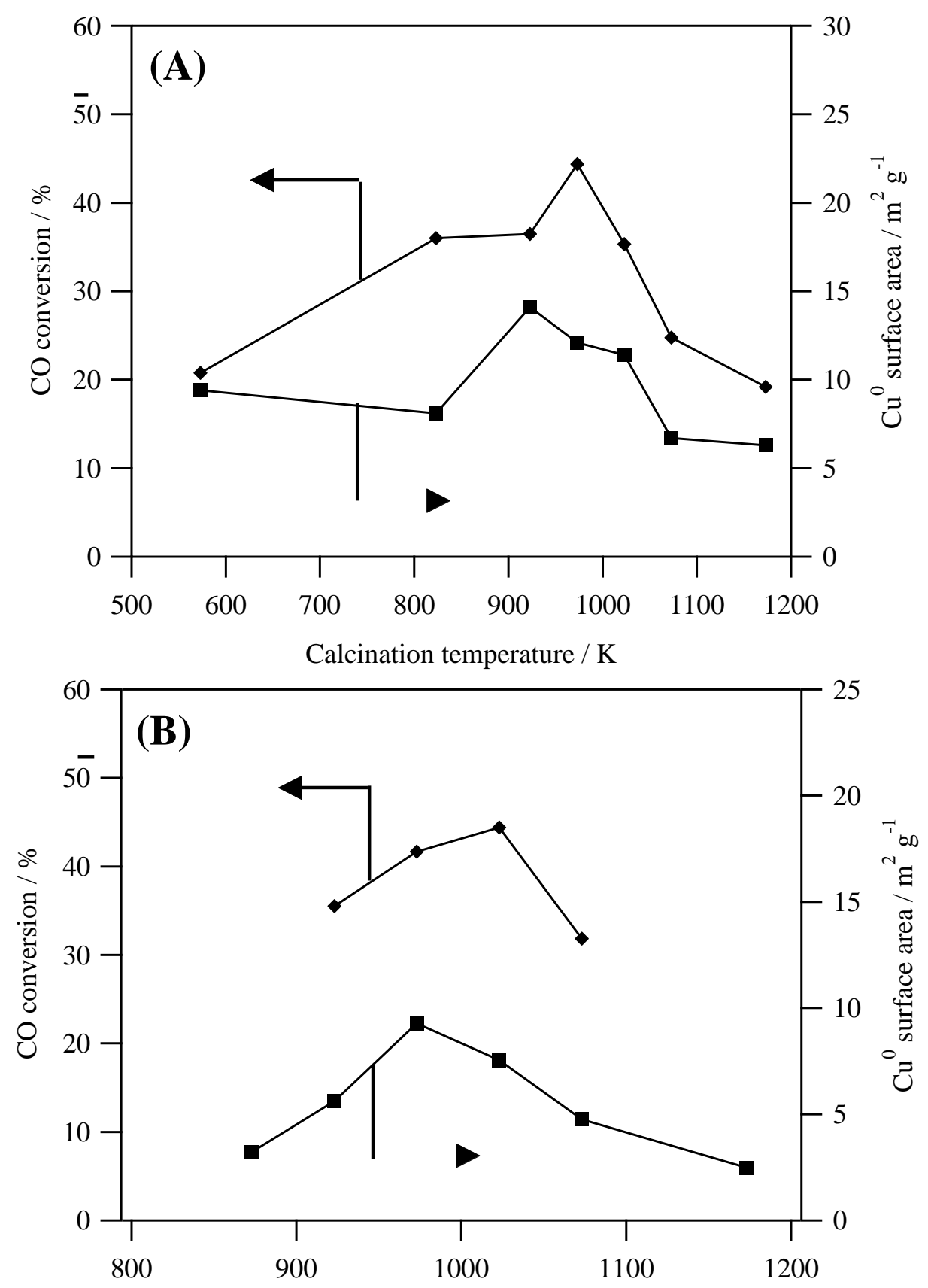

Calcination temperature / K

Fig. S2. Catalytic activity and $\mathrm{Cu}^{0}$ surface area of $\mathrm{Cu} / \mathrm{Al}_{2} \mathrm{O}_{3}$ catalysts as a function of calcination temperature. (A) $\mathrm{HP}$ - and (B) $\mathrm{SG}-\mathrm{Cu} / \mathrm{Al}_{2} \mathrm{O}_{3}$. Reaction temperature $473 \mathrm{~K}, \mathrm{CO} / \mathrm{CO}_{2} / \mathrm{H}_{2} \mathrm{O} / \mathrm{H}_{2}=7.3 / 7.3 / 27.2 / 58.3, \mathrm{GHSV}=12.4 \mathrm{~L} \mathrm{~h}^{-1} \mathrm{~g}^{-\mathrm{cat}^{-1}}$. 


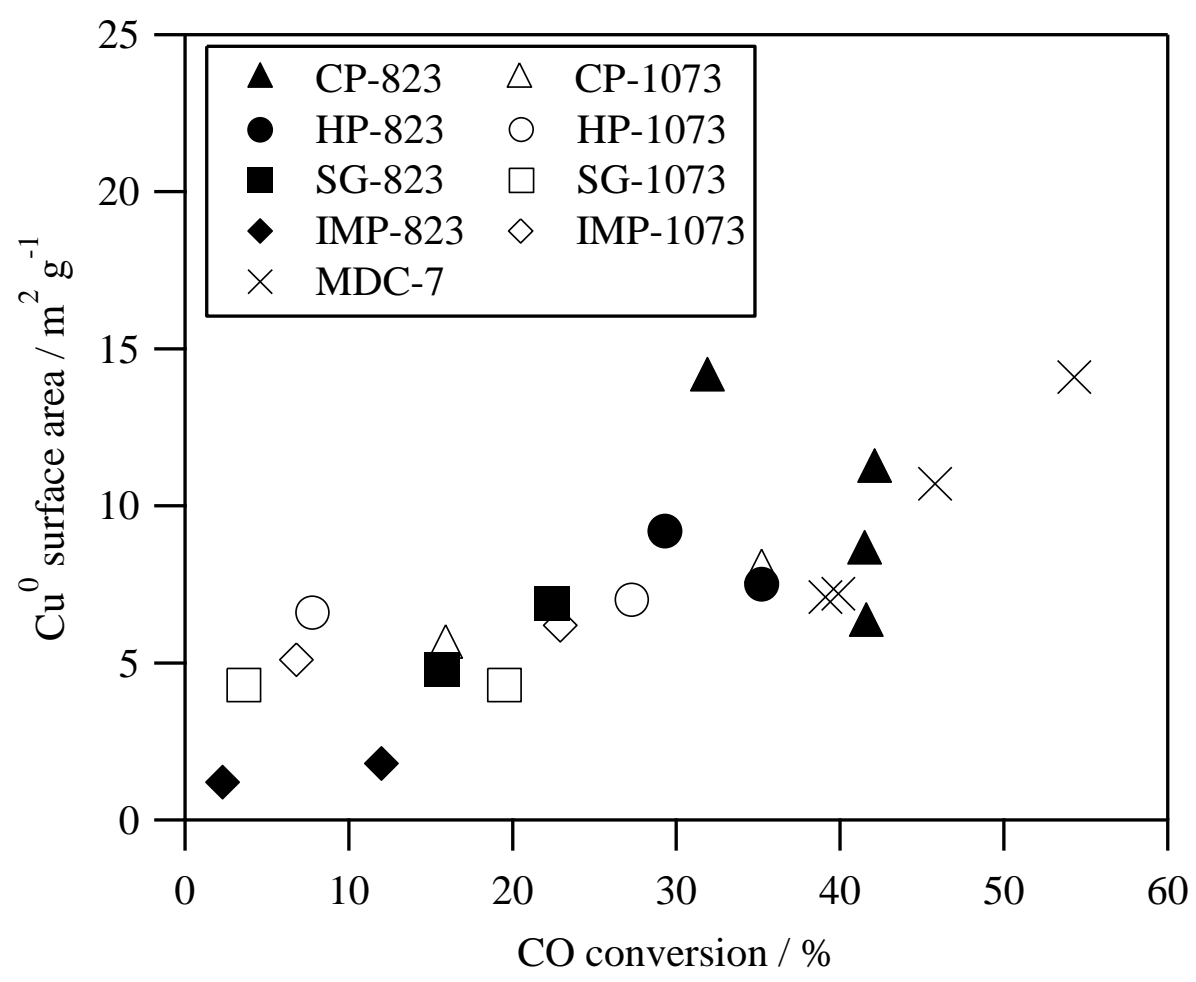

Fig. S3. The relationship between the catalytic activities and $\mathrm{Cu}$ metal surface area of the samples after DSS-like operations. 

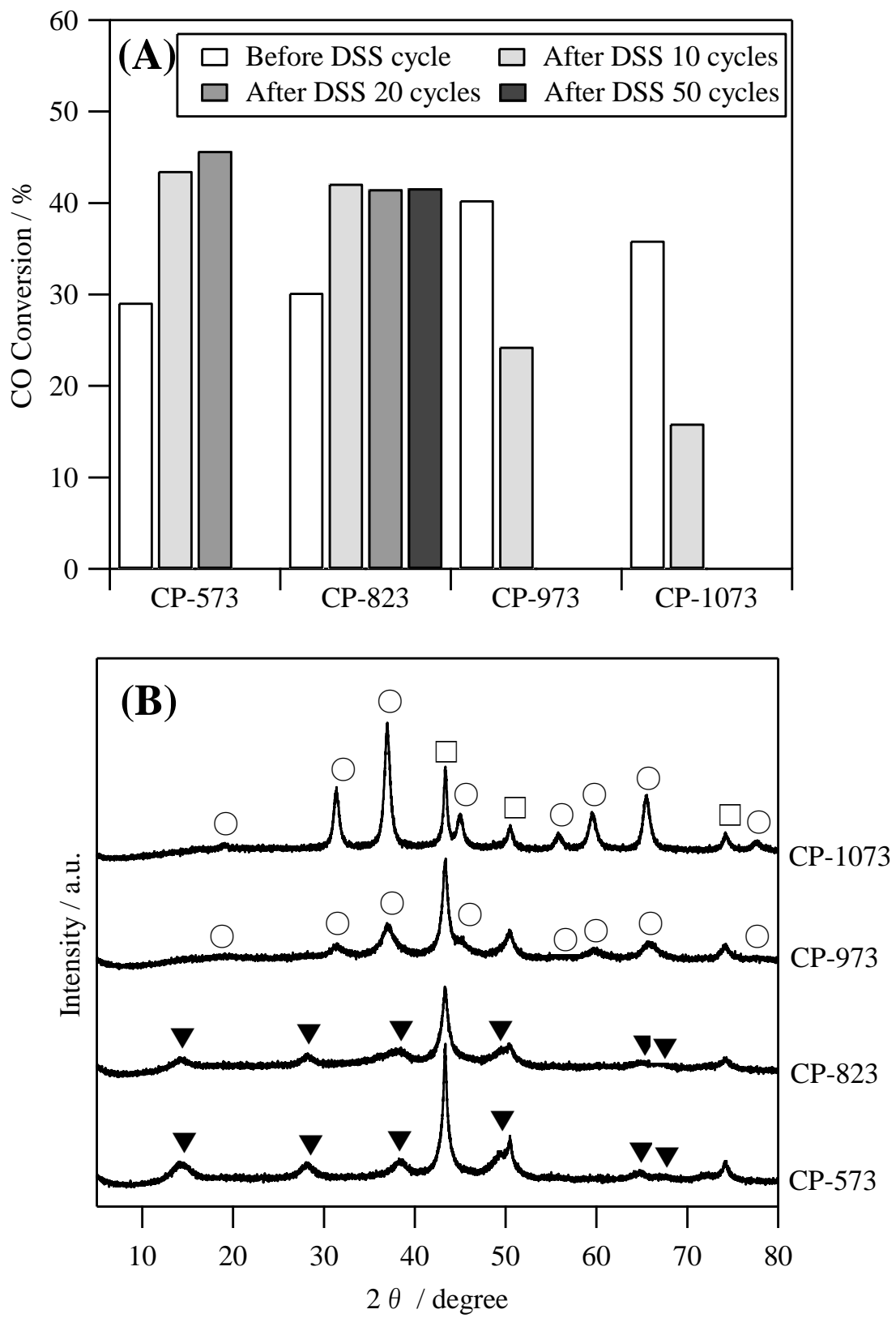

Fig. S4.

(A) The change in catalytic activity in the water-gas shift reaction by the DSS-like operation over $\mathrm{CP}-\mathrm{Cu} / \mathrm{Al}_{2} \mathrm{O}_{3}$ calcined at various temperatures. Reaction temperature $473 \mathrm{~K}, \mathrm{CO} / \mathrm{CO}_{2} / \mathrm{H}_{2} \mathrm{O} / \mathrm{H}_{2}=7.3 / 7.3 / 27.2 / 58.3, \mathrm{GHSV}=12.4 \mathrm{~L} \mathrm{~h}^{-1}$ g-cat $^{-1}$. (B) XRD patterns of $\mathrm{CP}-\mathrm{Cu} / \mathrm{Al}_{2} \mathrm{O}_{3}$ calcined at various temperature after 10 cycles of DSS operation, ( $\square) \mathrm{Cu}$ metal, $(\nabla) \mathrm{AlO}(\mathrm{OH}),(\bigcirc) \mathrm{CuAl}_{2} \mathrm{O}_{4}$. 

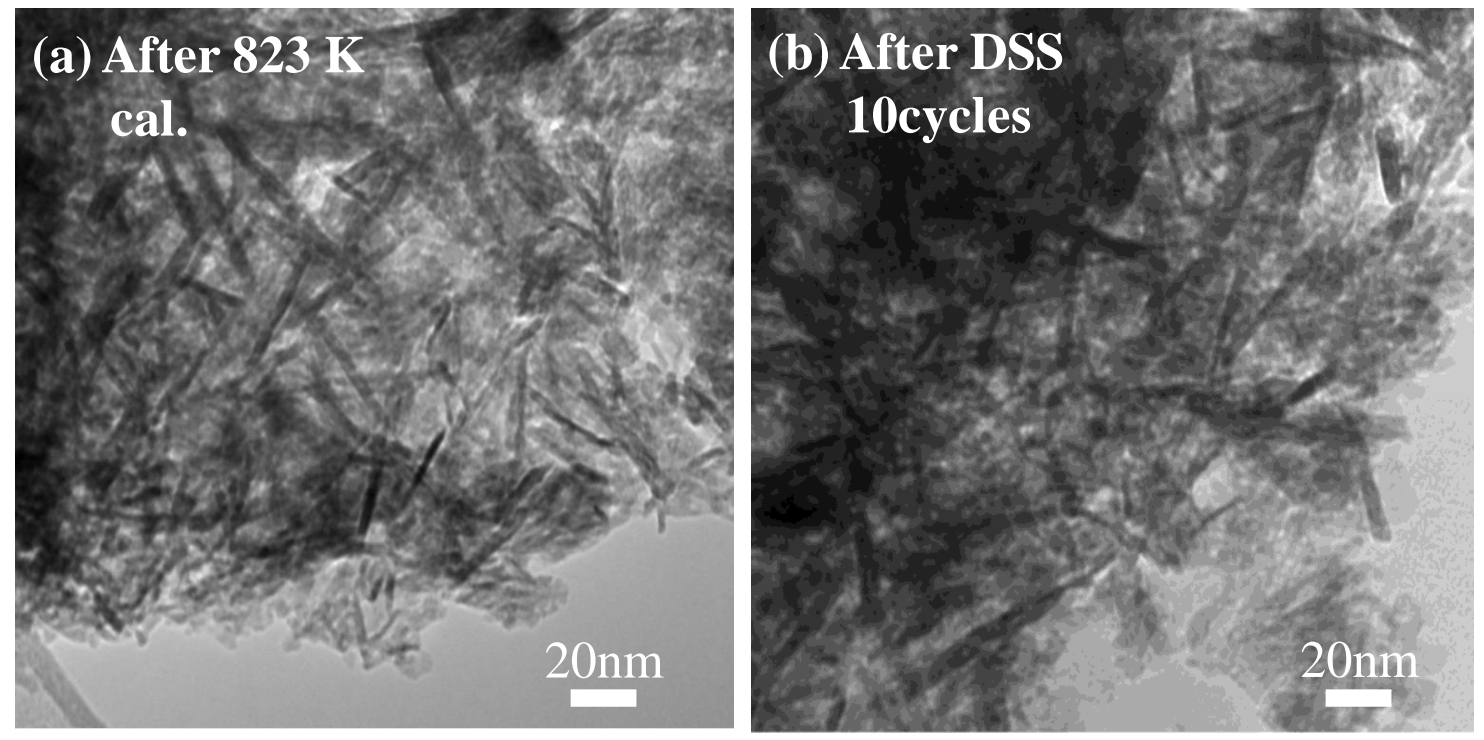

Fig. S5. TEM images of IMP-Cu/AIO(OH) catalysts before and after 10 cycles of DSS-like operation. 


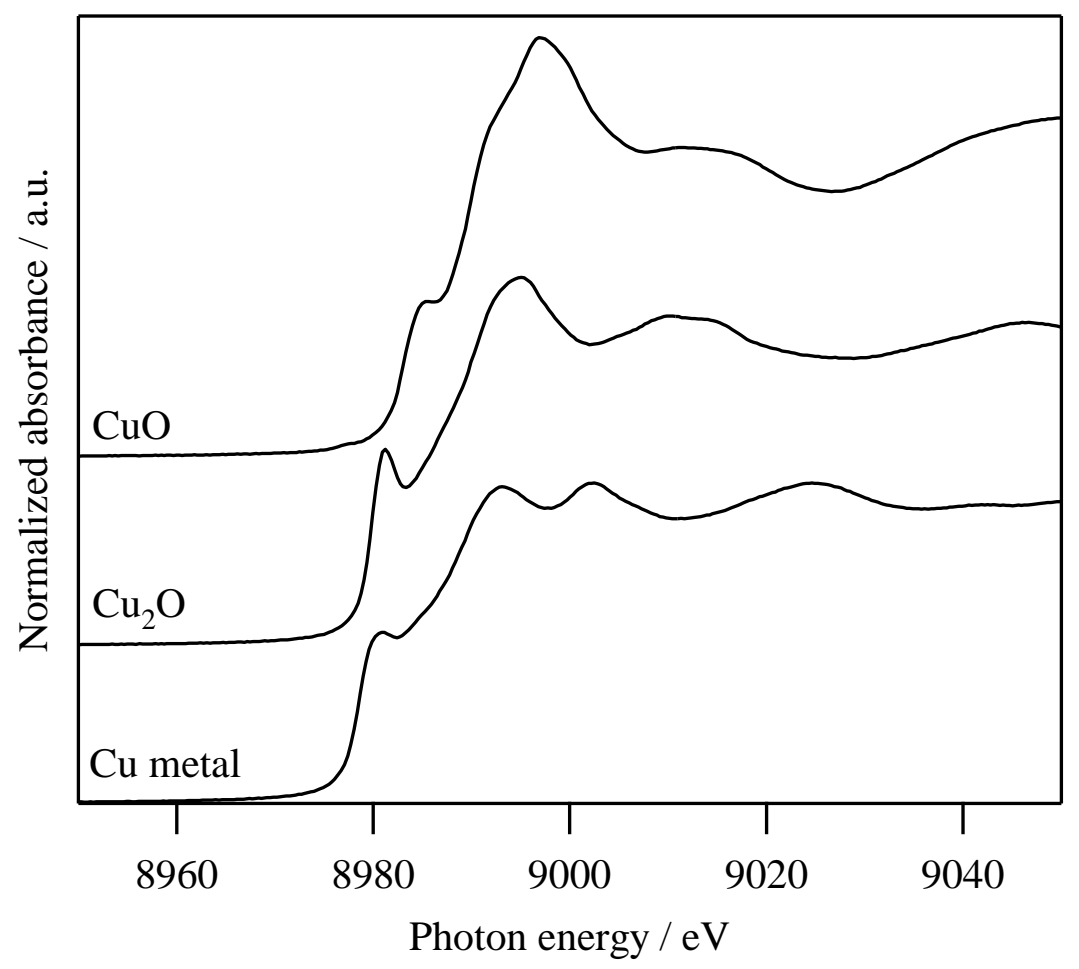

Fig. S6. $\mathrm{Cu}$ K-edge XANES spectra of $\mathrm{Cu}$ metal, $\mathrm{Cu}_{2} \mathrm{O}$, and $\mathrm{CuO}$ used as references. 